\title{
Photoperiod-modulated instar-specific clock-shifting in the circadian protein and amino acid rhythms in the larval segmental muscle of Bombyx mori
}

\author{
S. Sivaprasad* and B. Sailaja \\ Department of Zoology, Smt. N.P.S. Government College for Women, Chittoor-517 002 (A.P), INDIA \\ *Corresponding author. E-mail: sivaprasadzoology@ yahoo.co.in
}

\begin{abstract}
The photoperiod-modulated clock-shifting in the circadian protein rhythm was studied in the segmental muscle of Bombyx mori. The analysis of phase response curves of the fourth instar rhythm revealed that the muscle tissue completes six protein synthetic cycles (PS cycles) under normal $12 \mathrm{hr}$ light and $12 \mathrm{hr}$ dark cycle (LD), 8 cycles each under continuous light (LL) and continuous dark (DD) conditions. The fifth instar protein rhythm showed seven PS cycles each under LD and DD conditions, but only six under LL. The protein rhythm gets clock-shifted in instarspecific and photoperiod-specific fashions. In the fourth instar, both LL and DD conditions advanced the $24 \mathrm{hr}$ free running time of the rhythm by six hours and set it at $18 \mathrm{hr}$, but in the fifth instar it is delayed by $4 \mathrm{hr}$ and set at $\sim 28 \mathrm{hr}$ under LL, but remained unchanged under DD. Comparative analysis of protein and amino acid profiles shows that the photoperiod modulates the protein rhythm by altering the rate of amino acid mobilization.
\end{abstract}

Keywords: Bombyx mori, Circadian amino acid rhythm, Circadian protein rhythm, Segmental muscle, Photoperiod

\section{INTRODUCTION}

An illustrative account on the silkworm segmental musculature is now available (Sivaprasad and Muralimohan, 2009 a,b). It includes a series of inter- and intrasegmental striated muscles, attached to the body wall at specific regions of epicuticle including the intersegmental folds in the thorax and abdomen. The segmental muscles (SM) include dorsal, ventral and lateral groups, each comprising external and internal layers. The dorsal group includes the musculi dorsales interni mediales (DIM) and musculi dorsales interni laterales (DIL), musculi dorsales externi mediales (DEM) and musculi dorsales externi laterales (DEL), the ventral group includes musculi ventrales interni mediales (VIM) and musculi ventrales interni laterales (VIL), musculi ventrales externi mediales (VEM) and musculi ventrales externi laterales (VEL) and the lateral group includes the spiracular, tergosternal, tergopleural, tergocoxal, pleurosternal, sternocoxal and pleurocoxal muscles. The insect muscle performs a multitude of functions such as respiration, thermiogenesis, circulation of body fluids, body movements, maintenance of posture, oviposition, copulation, locomotion, jumping movements and in stabilizing joints (Kawasaki and Kita, 2004; Triplehorn and Johnson, 2005; Sivaprasad, 2010).

It is imperative to study the physiological and biochemical basis of insect muscle due to diverse habits and wide spread distribution of insects in almost every conceivable environment on the earth. The silkworm musculature is of special interest for its additional role in the cocoon spinning activity, which incidentally is the backbone of the sericulture industry. In order for the silkworm muscle to adapt effectively to stage-specific micro environmental conditions of larval, pupal and adult stages during metamorphosis, it should develop at the right place, achieve right size, grow into right muscle type and acquire right function. Further, it should acquire a variety of proteins involved in metabolism and contraction, so as to exhibit stage-specific behavioural responses in tune with the emerging metamorphic demands. A recent report on the proteomic profiles of silkworm muscle revealed the presence of 258 proteins involved in larval-pupal metamorphosis that vary in stage-specific manner (Zhang et al., 2007). Moreover, the insect tissues are known to contain endogenous pacemakers that modulate their metabolism and metamorphic behaviour (Xu et al., 2008), probably by causing rhythmic changes in its biochemical profiles including proteins. Evidently, the SM protein profiles of silkworm are subjected to rhythmic changes under the influence of light-sensitive endogenous circadian clock mechanism. Since, Bombyx mori is viewed as a potential model for the study of circadian biology, several investigations were carried out on the identification of circadian clocks, silk genes and their products (Ishikawa and Suzuki, 1985; Kimura et al., 1985; Obara and Suzuki, 1988; Michaille et al., 1989; Fukuta, et al., 1993; Gizelak, 1995; Sehadova et al., 2004; Iwai et al., 2006), which opened new vistas for probing the molecular and genetic basis of circadian clock mechanism in silkworm. However, 
no significant contributions have since been made on tissue-specific biochemical profiles vis-à-vis the impact of photoperiod on circadian rhythms, except for our preliminary investigations on the silk gland and fat body of the silkworm (Sailaja and Sivaprasad, 2010 a, 2010 b, 2011). In order to provide further impetus to studies in this direction, we made an attempt to analyze circadian changes in the segmental muscle protein and amino acid profiles in the silkworm during the fourth and fifth instar larval stages under the influence of altered photoperiodic conditions.

\section{MATERIALS AND METHODS}

The present investigation was carried out on the Pure Mysore $\mathrm{x} \mathrm{CSR}_{2}$ hybrid variety of the silkworm Bombyx mori, reared under standard environmental conditions of $28^{\circ} \mathrm{C}, 85 \% \mathrm{RH}$, as per Krishnaswami (1986). After hatching, the worms were reared on $\mathrm{M}_{5}$ mulberry leaves, with 5 feeds per day at 6AM, $10 \mathrm{AM}, 2 \mathrm{PM}, 6 \mathrm{PM}$ and 10 $\mathrm{PM}$ under $12 \mathrm{hr}$ light and $12 \mathrm{hr}$ dark cycle. After the third moult, the larvae were divided into three batches and reared separately under three different photoperiodic conditions, viz., $12 \mathrm{hr}$ light and $12 \mathrm{hr}$ dark cycle (LD), continuous light (LL) and continuous dark (DD) during fourth and fifth instars under the same feeding pattern. However, the remaining conditions, viz., temperature, food and the rearing environment are kept constant throughout the experiment, but the duration of photoperiod alone was altered so as to assess its impact on circadian protein and amino acid rhythms.

Circadian rhythmicity in the protein profiles, as reflected in hour-to-hour changes in their levels of the SM were analyzed during a $24 \mathrm{hr}$ period during the fourth instar and fifth instar larval stages. The segmental muscle, isolated every hour by dissecting the silkworm larvae in ice-cold Silkworm Ringer (Yamaoka et al., 1971), starting from $8 \mathrm{AM}$ on the day- 1 of experimentation through 8 AM on day-2 (i.e. for 25 hours), was used for the assay of proteins, both in the fourth and fifth instar larvae. The experiment lasted for two consecutive days encompassing 12: 12 hours of light and dark cycle (LD) for the first batch, continuous light (LL) for the second batch and continuous dark (DD) for the third batch. While, the larvae of 3-4 ${ }^{\text {th }}$ day were used during fourth instar, those of 5-6 day were used in the fifth instar. The levels of total and soluble proteins of the muscle tissue were estimated by the method of Lowry et al. (1951), in 1\% homogenates of the tissue in ice-cold distilled water. The rhythmic changes in the levels of structural proteins were obtained by subtracting the levels of soluble proteins from total proteins. The circadian changes in the levels of amino acids were assayed on bi-hourly basis by the method of Moore and Stein (1954) as described by Colowick and Kaplan (1957) in 10\% homogenates of the tissue in 10\%
TCA, during the same period. For analyzing instarspecific changes in rhythms, the larvae reared under LD condition of fourth instar was treated as control and that of fifth instar as experimental sample and for analyzing the impact of photoperiod on rhythms, the worms reared under LD condition of both fourth and fifth instar were treated as the control and those reared under LL and DD as experimental samples.

\section{RESULTS}

The $24 \mathrm{hr}$ circadian rhythmicity in the profiles of segmental muscle (SM) proteins and free amino acids, designated the free running period or tau, is shown in phase response curves (PRCs) in Figs. 1 to 5. The circadian data, obtained under three photoperiodic conditions, viz., 12:12 light / dark cycle (LD), continuous light (LL) and continuous dark (DD) was analyzed in terms of the number of peaks (elevated points) and troughs (low points or depressions) and intervals between them are presented in tables 1 to 5 . The protein and amino acid levels were expressed in $\mathrm{mg} / \mathrm{g}$ wet weight of muscle tissue.

Fourth instar larval rhythms

Total protein rhythm (Fig. 1A; Tables 1 and 2): Under $\mathrm{LD}$, the muscle total protein rhythm showed 5 peaks and 5 troughs during the $24 \mathrm{~h}$ free running period or tau. Peaks occurred at 08-11 hr (50 52 mg), $15 \mathrm{hr}(\sim 56 \mathrm{mg}), 17 \mathrm{hr}(\sim 53$ $\mathrm{mg})$ and again, next day at $01 \mathrm{hr}(\sim 51 \mathrm{mg})$ and $05 \mathrm{hr}(\sim 71$ $\mathrm{mg})$. Similarly, troughs were observed at 12-14 hr ( $\sim 2-46$ $\mathrm{mg}), 16 \mathrm{hr}(\sim 41 \mathrm{mg}), 20-22 \mathrm{hr}(\sim 37-41 \mathrm{mg})$ and next day at $02-03 \mathrm{hr}$ ( 46 mg each) and 07-08 hr ( 45-46 mg). Under LL, the rhythm recorded 6 peaks and 6 troughs. While the peaks appeared at $08 \mathrm{hr}(\sim 48 \mathrm{mg}), 11 \mathrm{hr}(\sim 49 \mathrm{mg}), 16$ $\mathrm{hr}(\sim 56 \mathrm{mg}), 00 \mathrm{hr}(\sim 56 \mathrm{mg})$ and again next day at $04 \mathrm{hr}$ $(\sim 52 \mathrm{mg})$ and $07 \mathrm{hr}(\sim 41 \mathrm{mg})$, troughs were observed at 09 $\mathrm{hr}(\sim 29 \mathrm{mg}), 14 \mathrm{hr}(\sim 40 \mathrm{mg}), 20 \mathrm{hr}(\sim 33 \mathrm{mg})$, and next day again at $01-02 \mathrm{hr}(\sim 39 \mathrm{mg}$ each $), 06 \mathrm{hr}(\sim 33 \mathrm{mg})$ and $08 \mathrm{hr}$ $(\sim 36 \mathrm{mg})$. The total protein rhythm of muscle recorded 8 peaks and 8 troughs under DD. Peaks occurred at $09 \mathrm{hr}$ $(\sim 53 \mathrm{mg}), 11 \mathrm{hr}(\sim 56 \mathrm{mg}), 13 \mathrm{hr}(\sim 67 \mathrm{mg}), 15 \mathrm{hr}(\sim 59 \mathrm{mg})$, $21 \mathrm{hr}(\sim 47 \mathrm{mg})$ and next day again at $01 \mathrm{hr}(\sim 46 \mathrm{mg}), 04 \mathrm{hr}$ $(\sim 53 \mathrm{mg})$ and $08 \mathrm{hr}(\sim 47 \mathrm{mg})$. Troughs appeared at $08 \mathrm{hr}$ $(\sim 43 \mathrm{mg}), 10 \mathrm{hr}(\sim 38 \mathrm{mg}), 12 \mathrm{hr}(44 \mathrm{mg}), 17 \mathrm{hr}(\sim 35 \mathrm{mg}), 19$ $\mathrm{hr}(\sim 32 \mathrm{mg}), 22-23 \mathrm{hr}(\sim 33 \mathrm{mg})$, and next day again at $02 \mathrm{hr}$ $(\sim 15 \mathrm{mg})$ and $06 \mathrm{hr}(\sim 36 \mathrm{mg})$.

Soluble protein r hythm (Fig. 1B; Tables land 2): Under $\mathrm{LD}$, the soluble protein rhythm of the SM showed 5 peaks and 7 troughs. Peaks appeared at $10 \mathrm{hr}(\sim 42 \mathrm{mg}), 13-15$ $(\sim 37-39 \mathrm{mg}), 17-19 \mathrm{hr}(\sim 32 \mathrm{mg}$ each) and next day at $01 \mathrm{hr}$ $(\sim 35 \mathrm{mg})$ and $04-05 \mathrm{hr}(\sim 37-38 \mathrm{mg})$. Troughs made their appearance at $08 \mathrm{hr}(25 \mathrm{mg}), 12 \mathrm{hr}(\sim 19 \mathrm{mg}), 16 \mathrm{hr}(\sim 27$ $\mathrm{mg}), 20 \mathrm{hr}(\sim 18 \mathrm{mg}), 22 \mathrm{hr}(\sim 21 \mathrm{mg})$ and next day at $03 \mathrm{hr}$ $(\sim 27 \mathrm{mg})$ and $08 \mathrm{hr}(\sim 25 \mathrm{mg})$. Under LL, 6 peaks and 6 troughs were recorded in the rhythm. Peak occurred at 


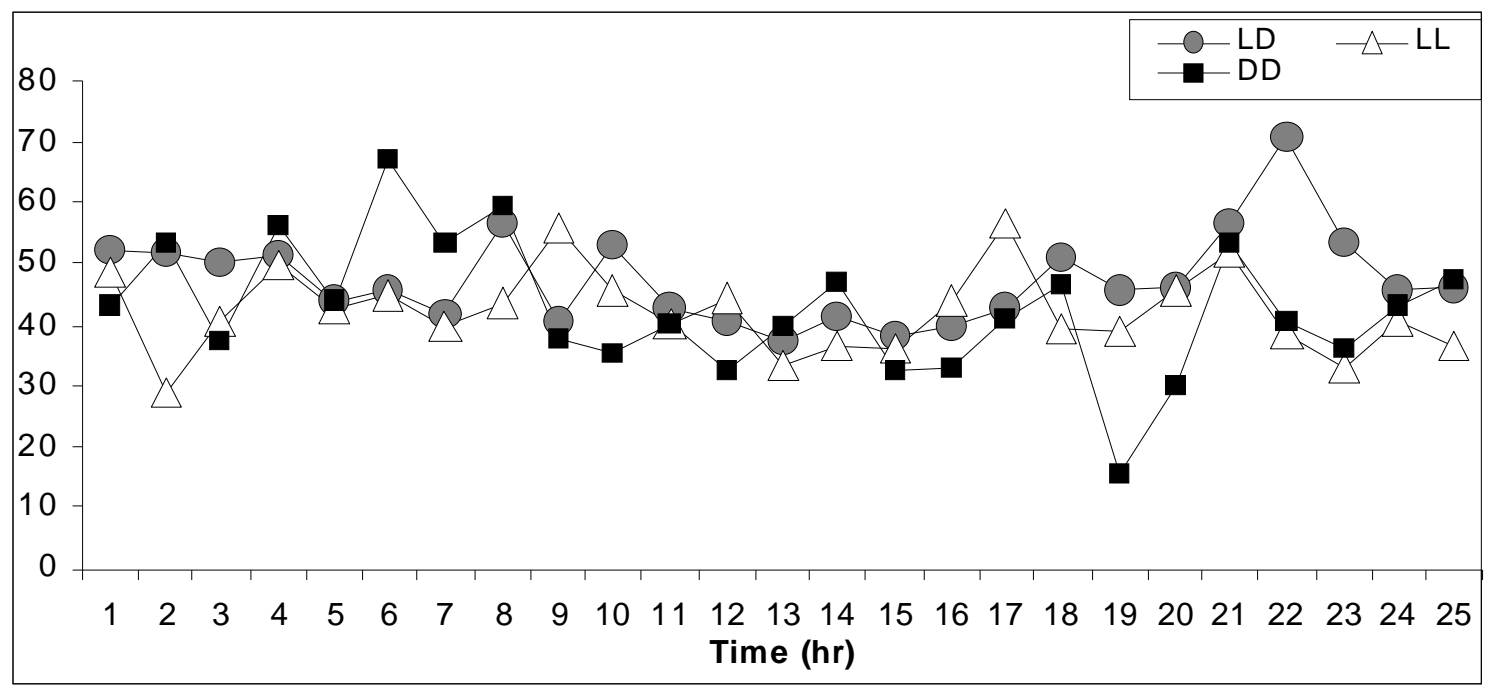

A. M uscle total protein rhythm in IV instar $(\mathrm{mg} / \mathrm{g})$.

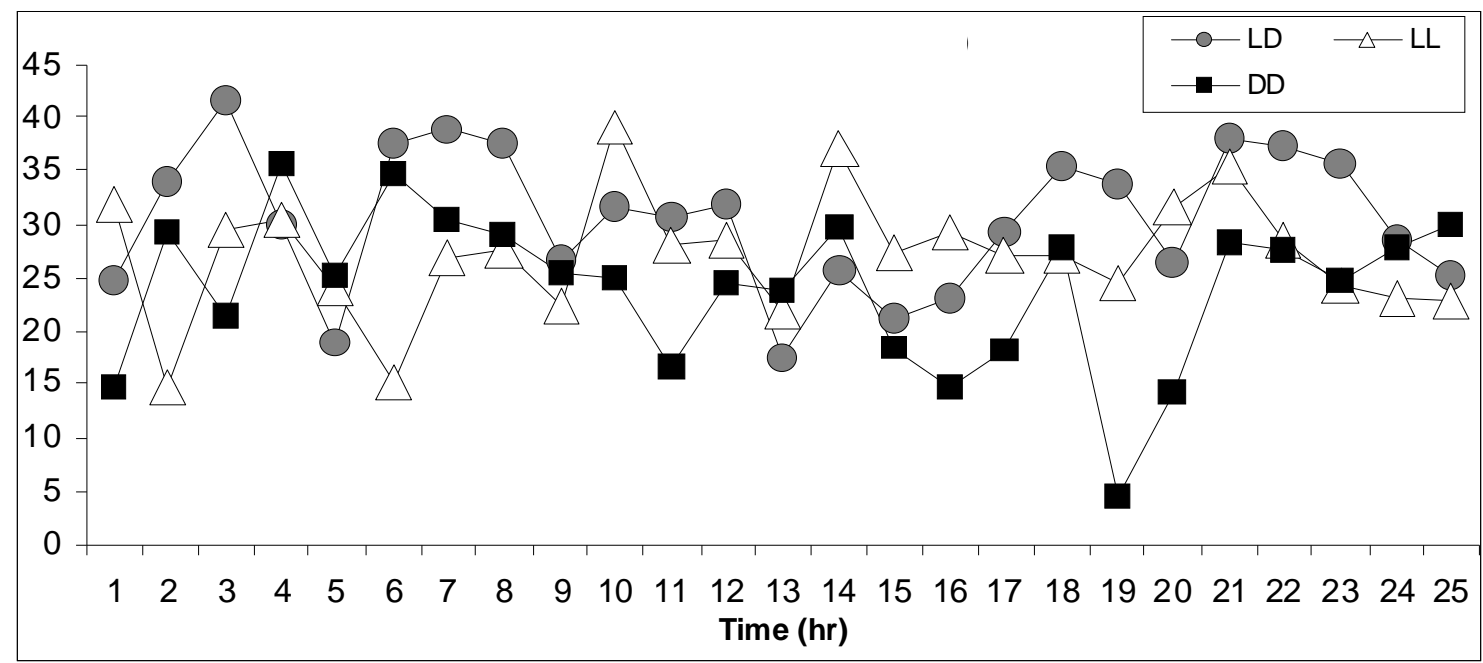

B. M uscle soluble protein protein rhythm in IV instar $(\mathrm{mg} / \mathrm{g})$.

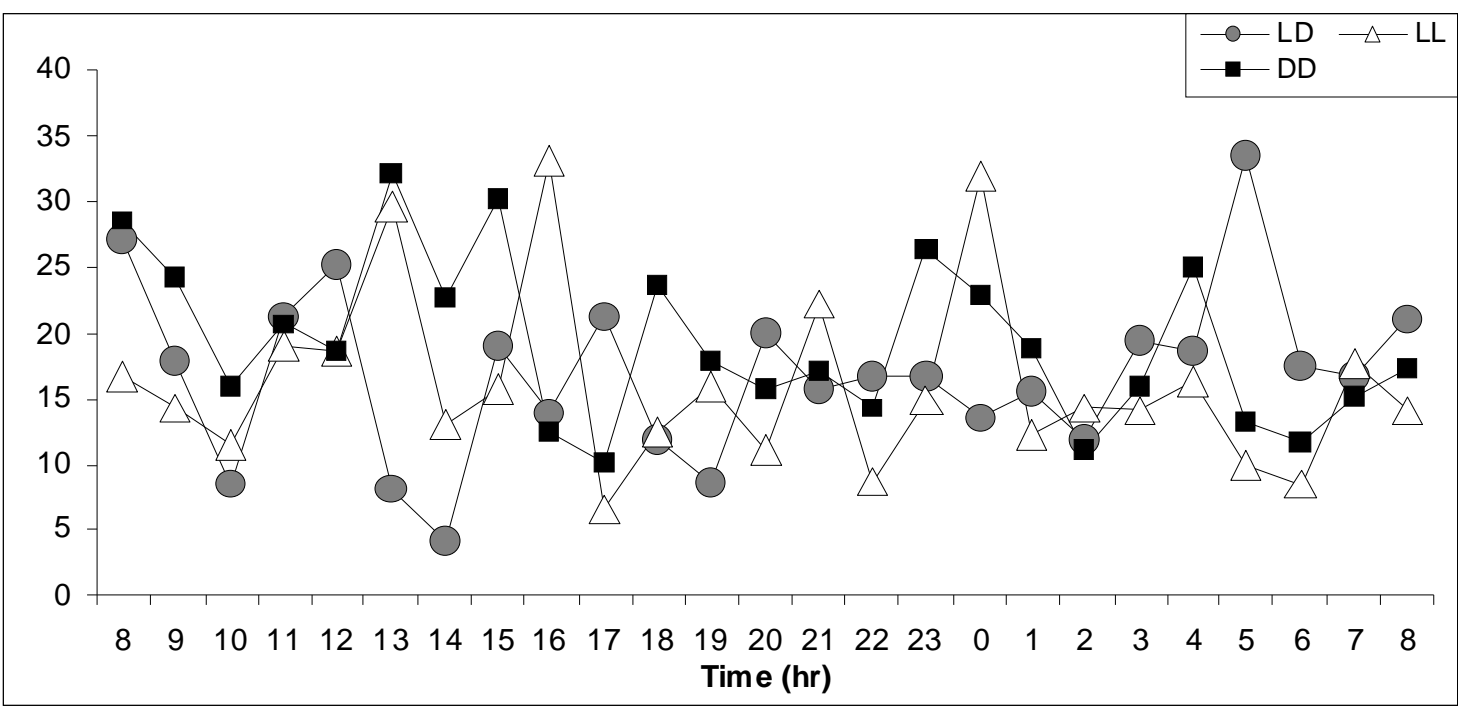

C. M uscle structural protein rhythm in IV instar $(\mathrm{mg} / \mathrm{g})$.

Fig. 1. Phase response curves (PRCs) of the $24 \mathrm{hr}$ circadian protein rhythms (from $8 \mathrm{AM}$ on day 3 to $8 \mathrm{AM}$ on day 4 ) in the skel etal muscle of the fourth instar larva of Bombyx mori, under three photoperiodic conditions, viz., $12 \mathrm{~h}$ light: $12 \mathrm{~h}$ dark cycle (LD); continuous light (LL) and continuous dark (DD ). A. Total proteins; B. soluble proteins and C. structural proteins $(P<0.001)$. 


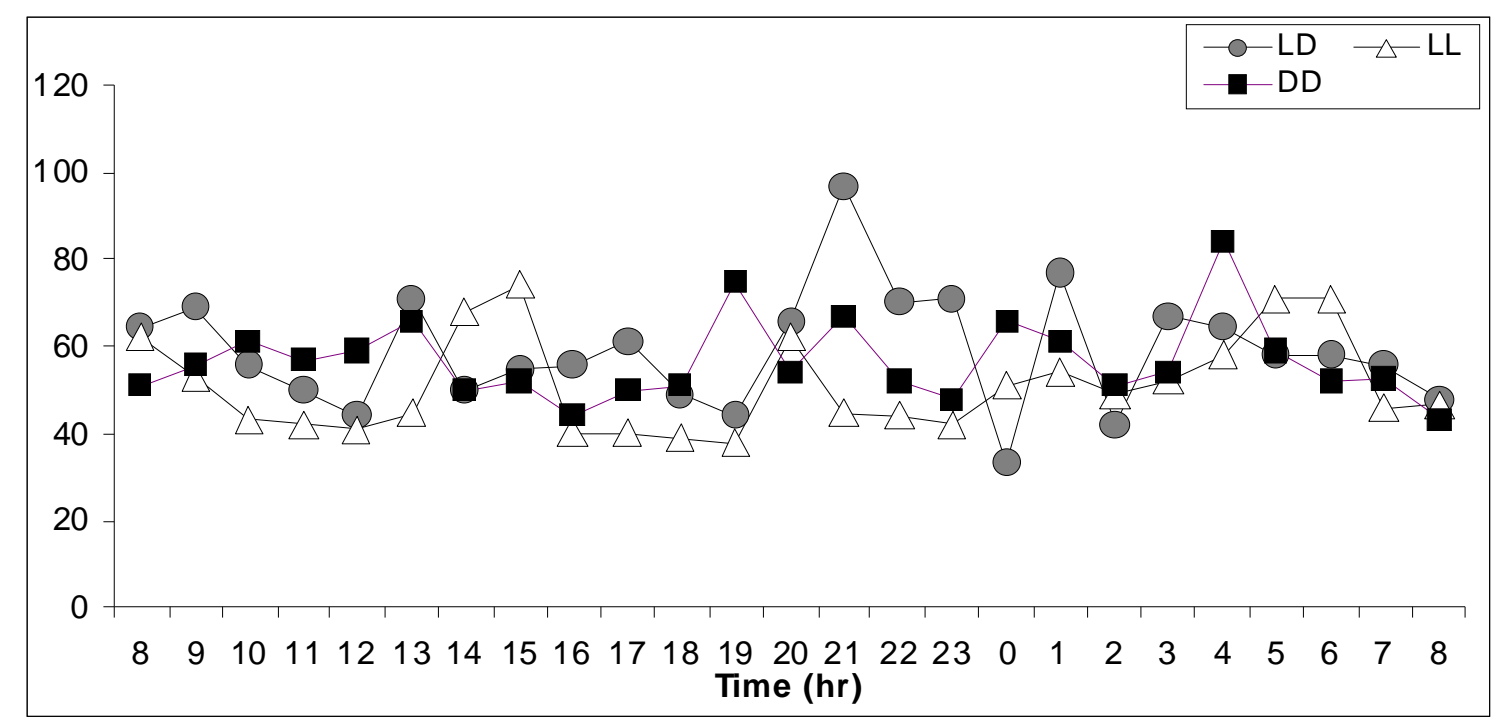

A. Muscle total protein in rhythm in $\mathrm{V}$ instar $(\mathrm{mg} / \mathrm{g})$.

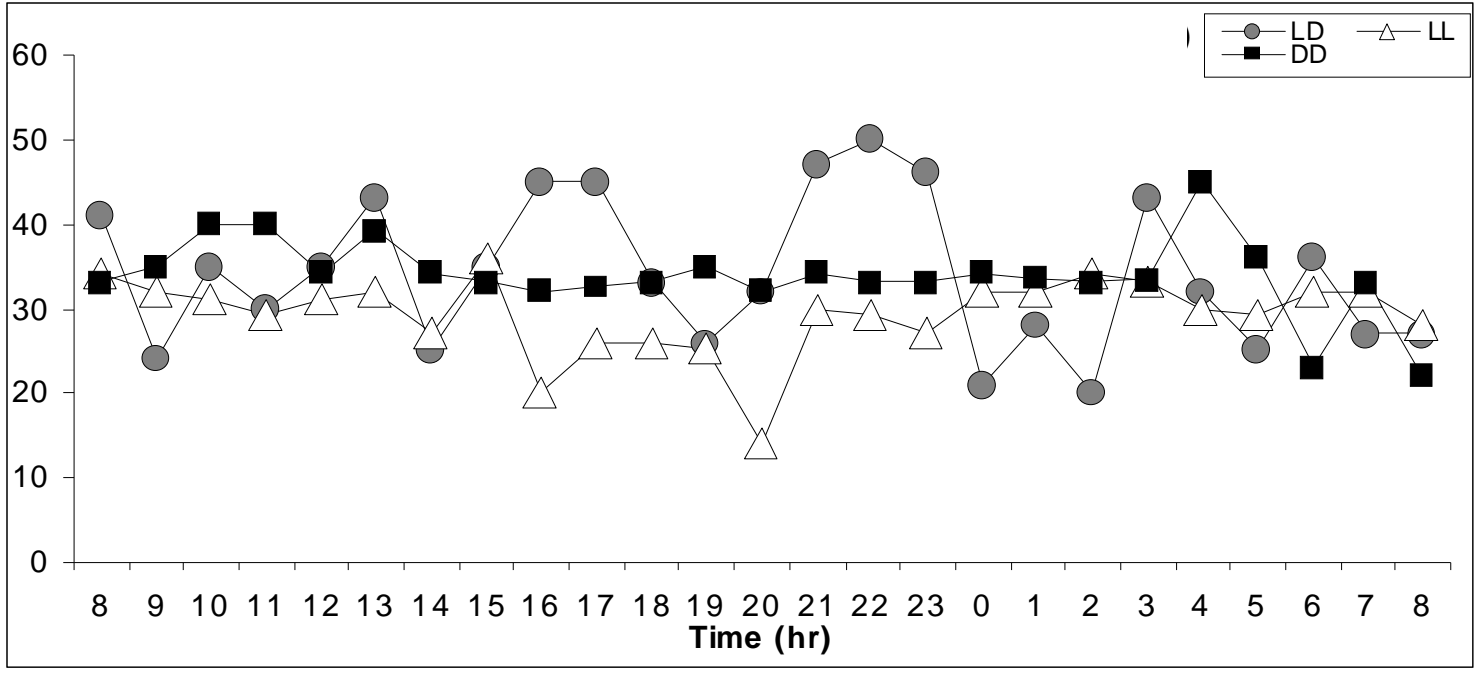

B. M uscle soluble protein in rhythm in V instar $(\mathrm{mg} / \mathrm{g})$.

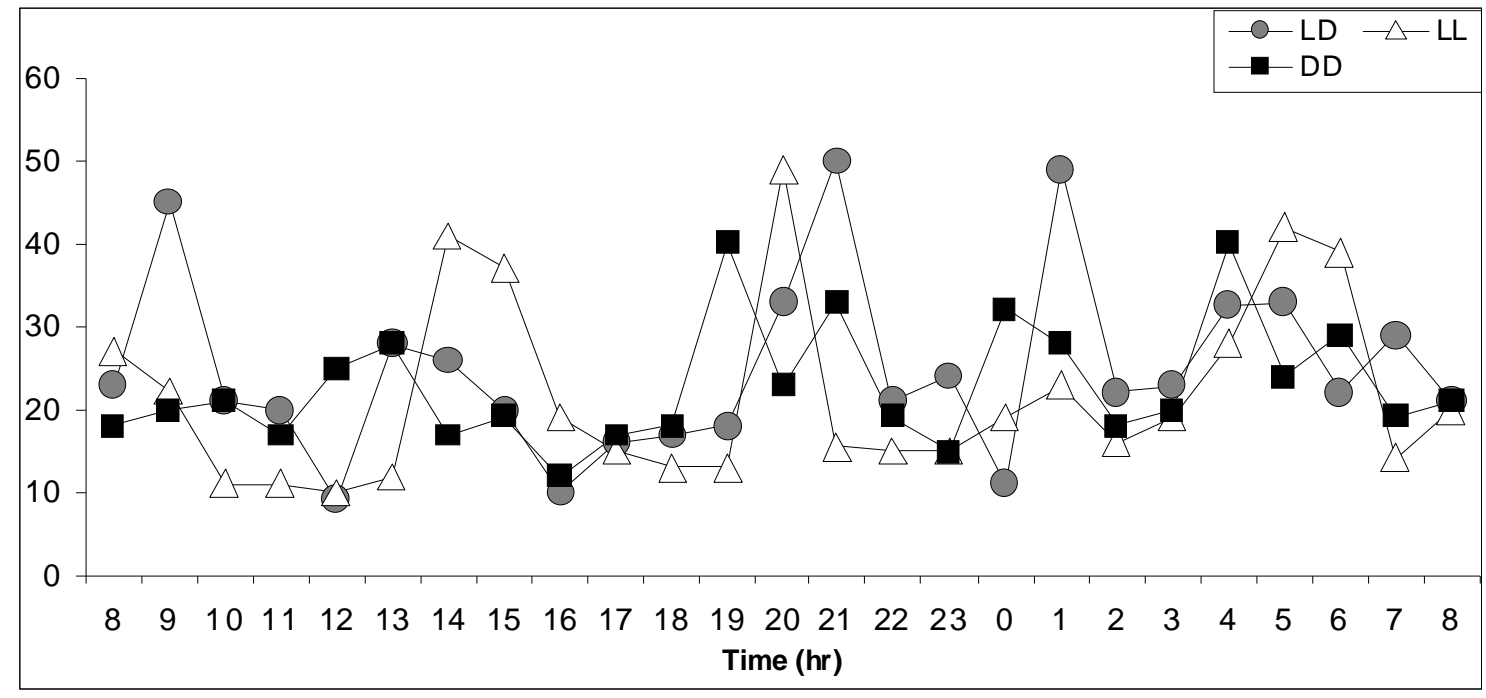

C. M uscle structural protein rhythm in $\mathrm{V}$ instar $(\mathrm{mg} / \mathrm{g})$.

Fig. 2. Phase response curves (PRCs) of the $24 \mathrm{hr}$ circadian protein rhythms (from $8 \mathrm{AM}$ on day 5 to $8 \mathrm{AM}$ on day 6 ) in the skeletal muscle of the fifth instar larva of Bombyx mori, under three photoperiodic conditions, viz., $12 \mathrm{~h}$ light: $12 \mathrm{~h}$ dark cycle (LD); continuous light (LL) and continuous dark (DD ). A. Total proteins; B. Soluble proteins and C. Structural proteins $(P<0.001)$. 


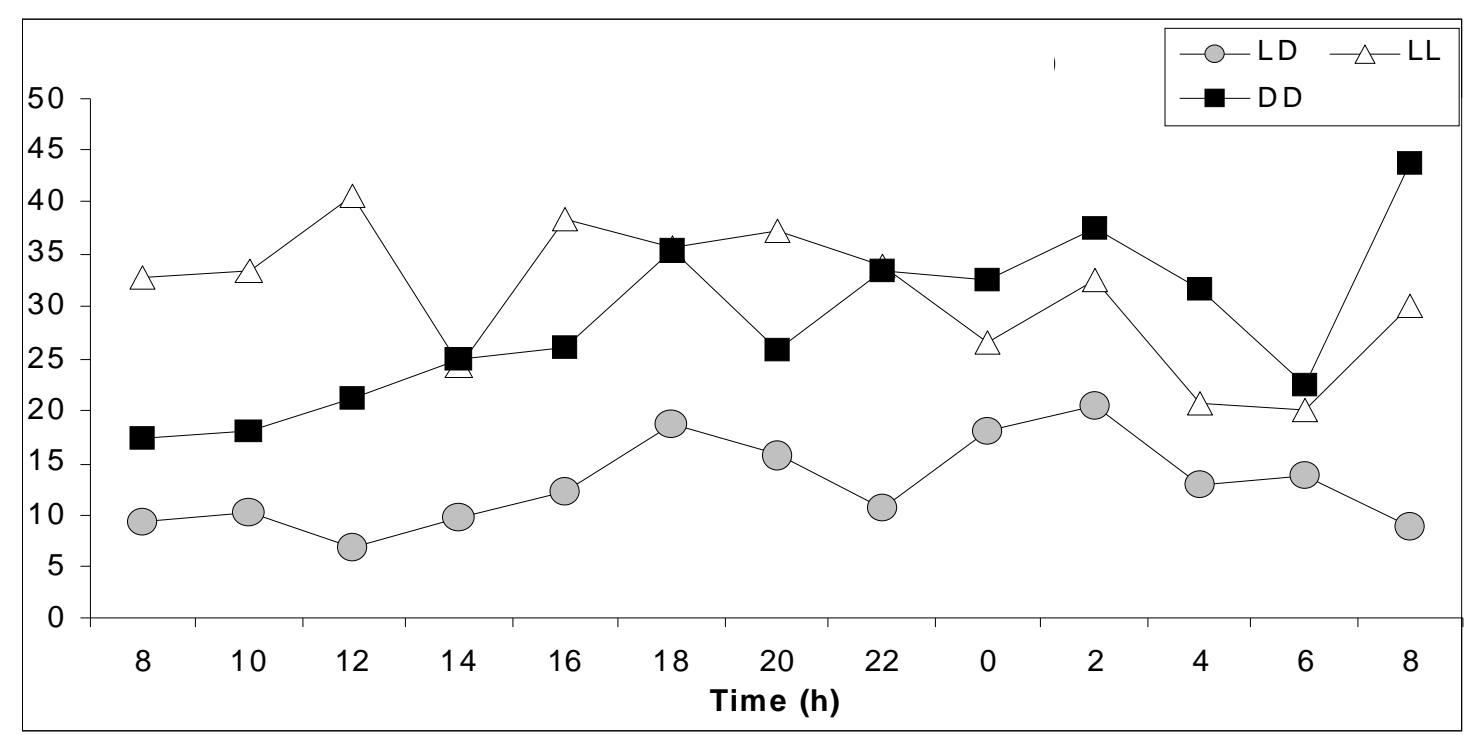

A. M uscle amino acid rhythm - IV instar (mg/g).

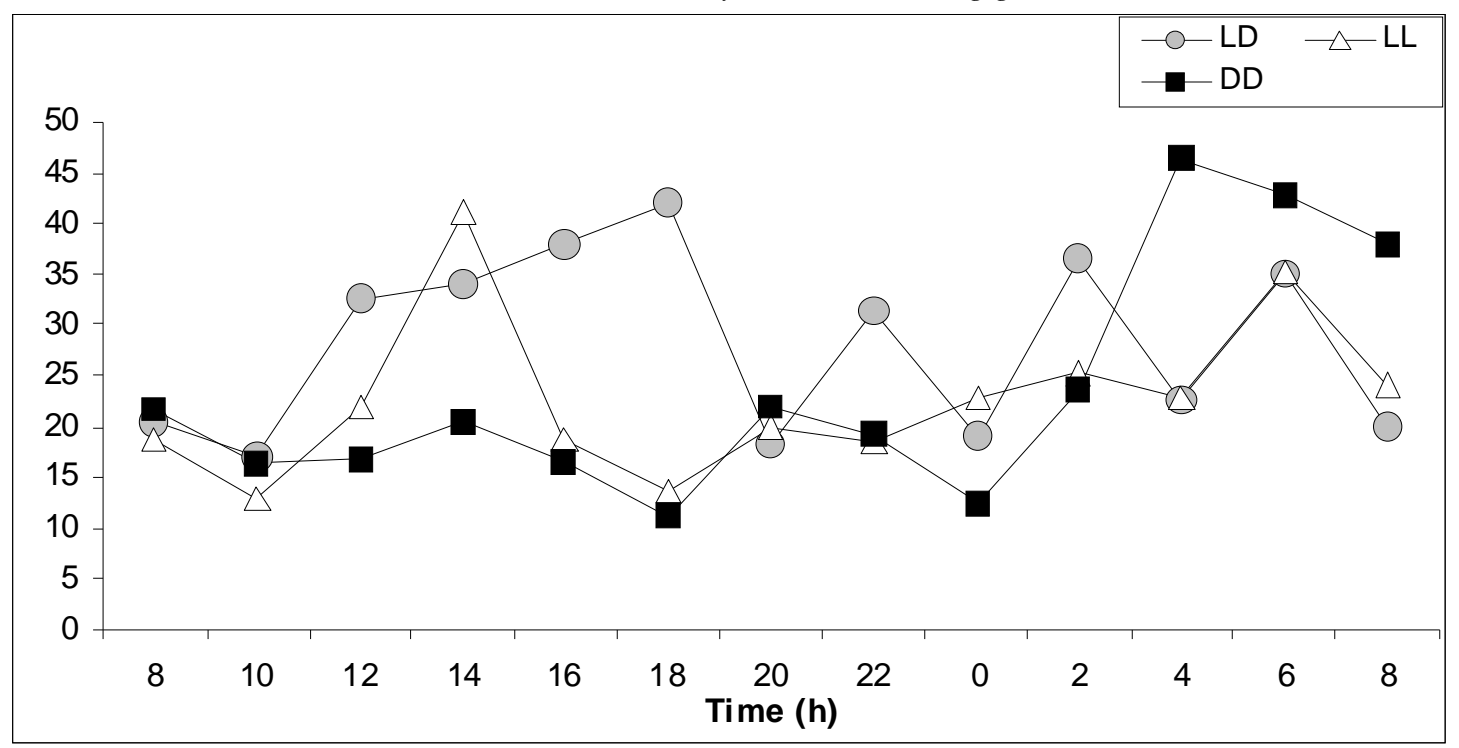

B. M uscle amino acid rhythm - V instar ( $\mathrm{mg} / \mathrm{g})$.

Fig. 3. Phase response curves ( $P R C)$ of the 24 -hr circadian amino acid rhythms in the skel etal muscle of $(A)$ fourth instar (from 8AM on day-3 to 8 AM on day-4) and (B) fifth instar (from 8AM on day-5 to 8 AM on day-6) larvae of Bombyx mori, under three photoperiodic conditions, viz., $12 \mathrm{~h}$ light: $12 \mathrm{~h}$ dark cycle (LD); continuous light (LL) and continuous dark (DD) conditions (Source: Table 4.13). $(P<0.001)$.

$08 \mathrm{hr}(\sim 32 \mathrm{mg}), 11 \mathrm{hr}(\sim 31 \mathrm{mg}), 15 \mathrm{hr}(\sim 28 \mathrm{mg}), 17 \mathrm{hr}(39$ $\mathrm{mg}), 21 \mathrm{hr}(37 \mathrm{mg})$ and next day again at $04 \mathrm{hr}(\sim 35 \mathrm{mg})$. Troughs were recorded at $09 \mathrm{hr}(\sim 15 \mathrm{mg}), 13 \mathrm{hr}(15 \mathrm{mg})$, $16 \mathrm{hr}(\sim 23 \mathrm{mg}), 20 \mathrm{hr}(\sim 22 \mathrm{mg})$ and next day at $02 \mathrm{hr}(\sim 25$ $\mathrm{mg})$ and $08 \mathrm{hr}(\sim 23 \mathrm{mg})$. Under DD the soluble protein rhythm recorded 7 peaks and 7 troughs. Peaks appeared at $09 \mathrm{hr}(\sim 29 \mathrm{mg}), 11 \mathrm{hr}(\sim 36 \mathrm{mg}), 13 \mathrm{hr}(\sim 35 \mathrm{mg}), 21 \mathrm{hr}$ $(\sim 30 \mathrm{mg})$ and next day at $01 \mathrm{hr}(\sim 28 \mathrm{mg}), 04 \mathrm{hr}(\sim 28 \mathrm{mg})$ and $08 \mathrm{hr}(30 \mathrm{mg})$. Troughs, occurred at $08 \mathrm{hr}(\sim 15 \mathrm{mg}), 10$ $\mathrm{hr}(\sim 22 \mathrm{mg}), 12 \mathrm{hr}(\sim 25 \mathrm{mg}), 18 \mathrm{hr}(\sim 17 \mathrm{mg}), 23 \mathrm{hr}(\sim 15 \mathrm{mg})$ and next day at $02 \mathrm{hr}(\sim 4 \mathrm{mg})$ and $06 \mathrm{hr}(\sim 25 \mathrm{mg})$.

Structural protein rhythm (Fig. 1C; Tables 1 and 2):

Under LD, the structural proteins rhythm showed 6 peaks and 6 troughs during the $24 \mathrm{hr}$ free running period. Peaks appeared at $08 \mathrm{hr}(\sim 27 \mathrm{mg}), 12 \mathrm{hr}(\sim 25 \mathrm{mg}), 15 \mathrm{hr}(\sim 19 \mathrm{mg})$, $17 \mathrm{hr}(\sim 21 \mathrm{mg}), 20 \mathrm{hr}(\sim 20 \mathrm{mg})$ and next day again at $05 \mathrm{hr}$ $(\sim 34 \mathrm{mg})$. Troughs made their appearance at $10 \mathrm{hr}(\sim 8$ $\mathrm{mg}), 14 \mathrm{hr}(\sim 4 \mathrm{mg}), 16 \mathrm{hr}(\sim 14 \mathrm{mg}), 19 \mathrm{hr}(\sim 9 \mathrm{mg})$ and next day at $02 \mathrm{hr}(\sim 12 \mathrm{mg})$ and $06-07 \mathrm{hr}(\sim 17 \mathrm{mg}$ each). Under LL, 8 peaks and 8 troughs were recorded in the levels of structural proteins of the muscle. Peaks occurred at $08 \mathrm{hr}$ $(\sim 17 \mathrm{mg}), 13 \mathrm{hr}(\sim 30 \mathrm{mg}), 16 \mathrm{hr}(\sim 33 \mathrm{mg}), 19 \mathrm{hr}(\sim 16 \mathrm{mg})$, $21 \mathrm{hr}(\sim 22 \mathrm{mg}), 00 \mathrm{hr}(\sim 32 \mathrm{mg})$ and next day at $04 \mathrm{hr}(\sim 16$ $\mathrm{mg})$ and again at $07 \mathrm{hr}(\sim 18 \mathrm{mg})$. Troughs were recorded at $10 \mathrm{hr}(\sim 11 \mathrm{mg}), 14 \mathrm{hr}(\sim 13 \mathrm{mg}), 17 \mathrm{hr}(\sim 7 \mathrm{mg}), 20 \mathrm{hr}(\sim 11$ $\mathrm{mg}), 22 \mathrm{hr}(\sim 9 \mathrm{mg})$, and next day at $01 \mathrm{hr}(\sim 12 \mathrm{mg}), 06 \mathrm{hr}$ $(\sim 9 \mathrm{mg})$ and $08 \mathrm{hr}(\sim 14 \mathrm{mg})$. DD condition caused 7 peaks 


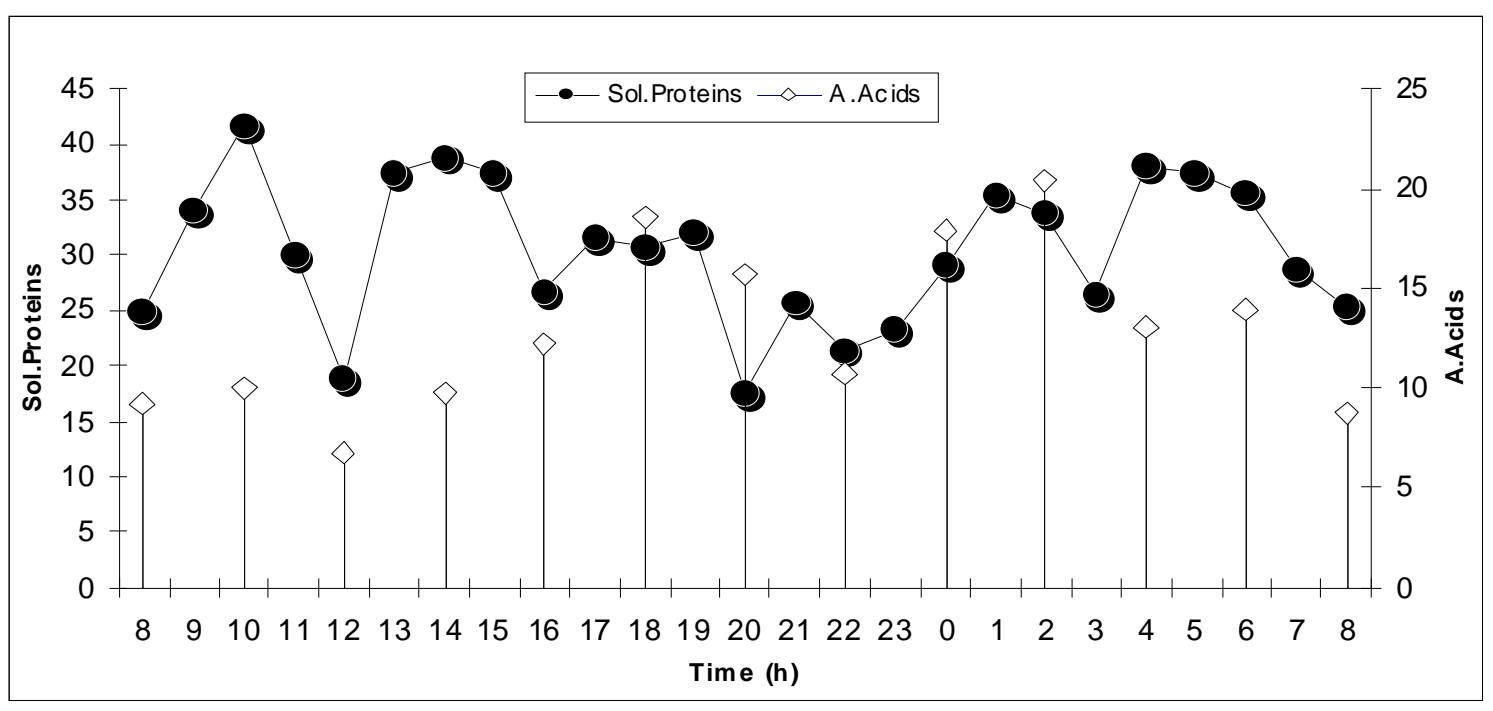

A. M uscle soluble proteins $\mathrm{v} / \mathrm{s}$ amino acids $(\mathrm{mg} / \mathrm{g})$ in IV instar under LD.

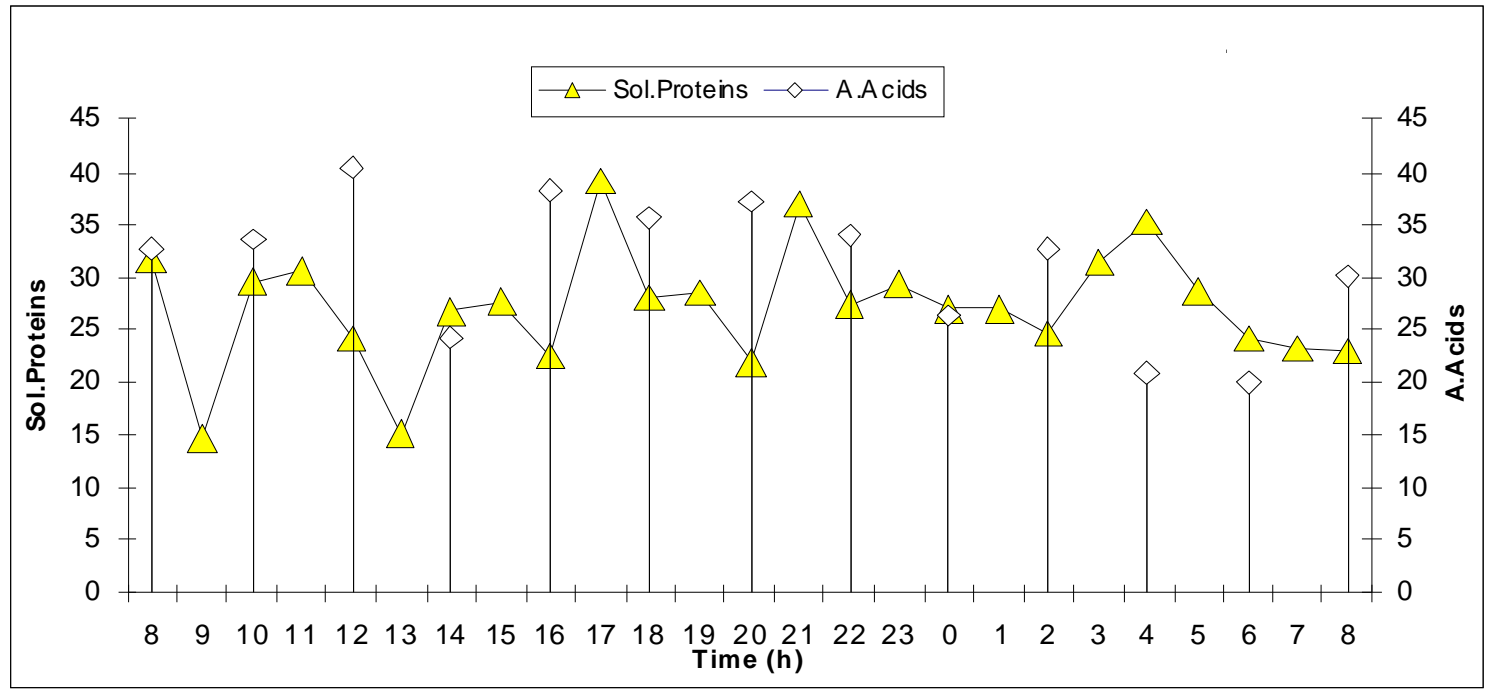

B. M uscle soluble proteins $\mathrm{v} / \mathrm{s}$ amino acids $(\mathrm{mg} / \mathrm{g}$ ) in IV instar under $\mathrm{LL}$.

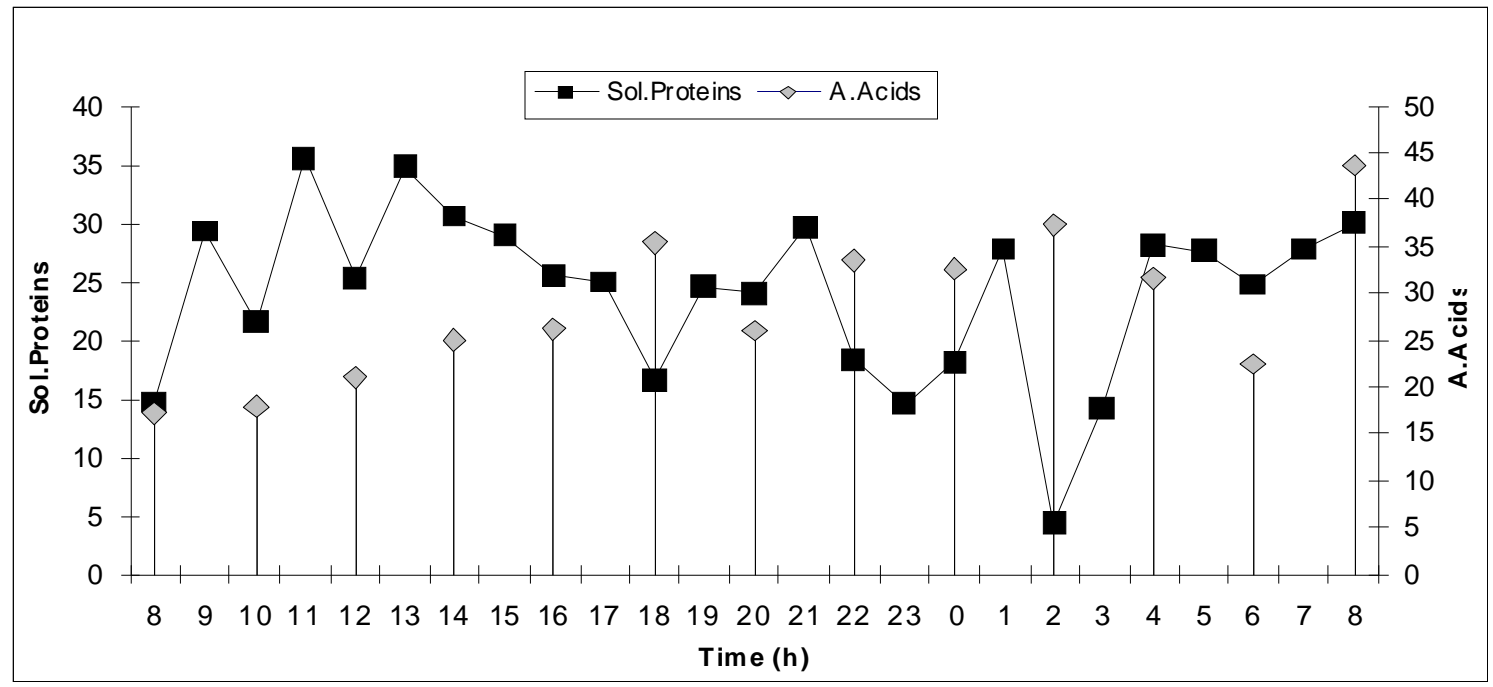

C. M uscle soluble proteins $\mathrm{v} / \mathrm{s}$ amino acids $(\mathrm{mg} / \mathrm{g})$ in IV instar under D D.

Fig.4. Circadian changes in profiles of soluble proteins and free amino acids in the skeletal muscle of the fourth instar larva of Bombyx mori, under (A) $12 \mathrm{hr}$ light: $12 \mathrm{hr}$ dark cycle (LD), (B): continuous light and (C) continuous dark (DD) conditions. The values expressed in mg per gm-wet weight of tissue, represent $24 \mathrm{hr}$ (8 AM on day-3 to 8A.M on day 4) free running time of the circadian rhythm. 


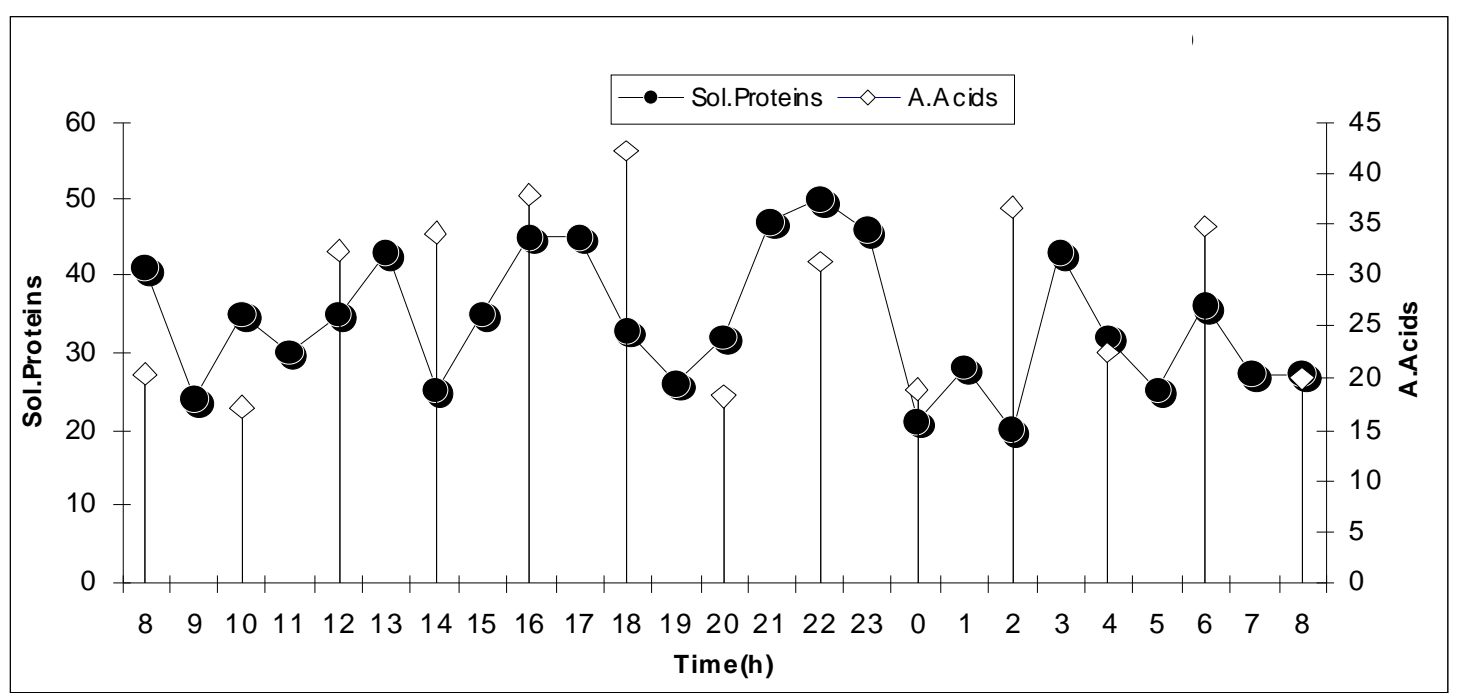

A. M uscle soluble proteins $\mathrm{v} / \mathrm{s}$ amino acids $(\mathrm{mg} / \mathrm{g})$ in $\mathrm{V}$ instar under $\mathrm{LD}$.

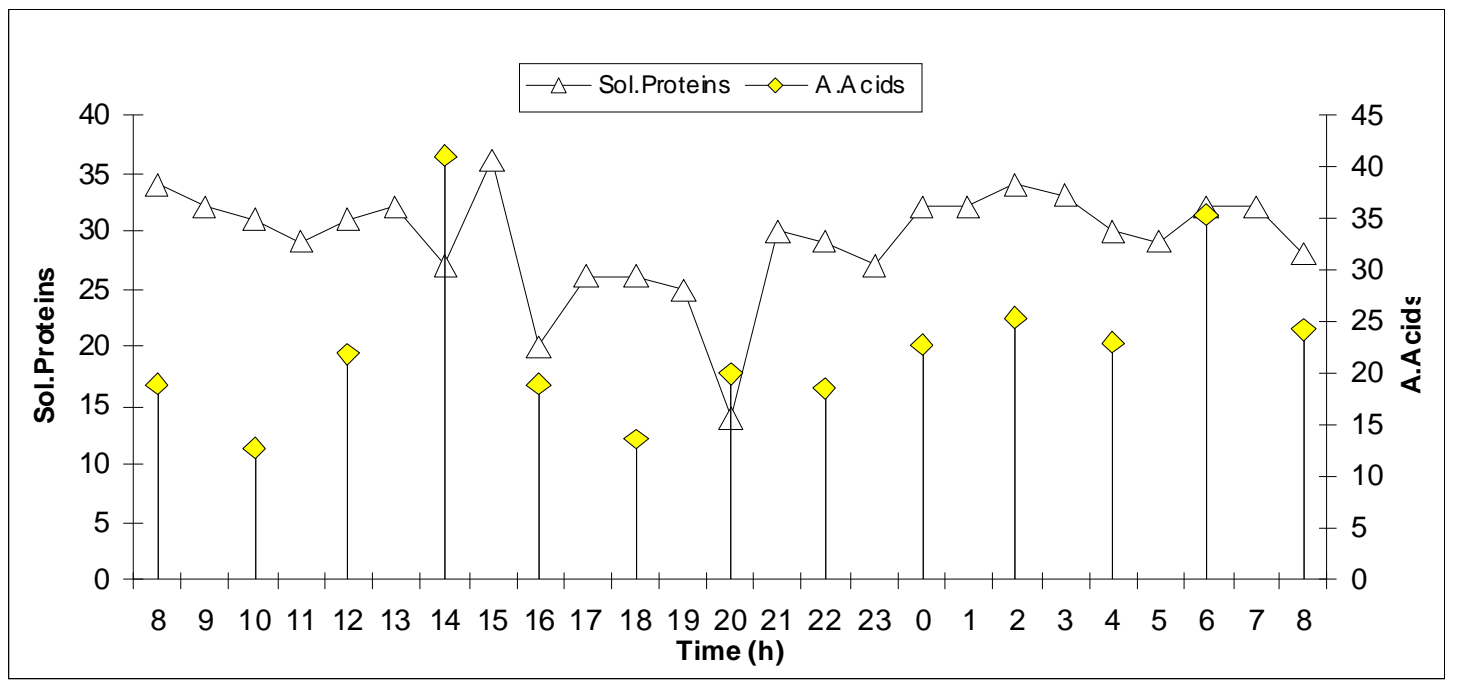

B. M uscle soluble proteins $\mathrm{v} / \mathrm{s}$ amino acids $(\mathrm{mg} / \mathrm{g})$ in V instar under $\mathrm{LL}$.

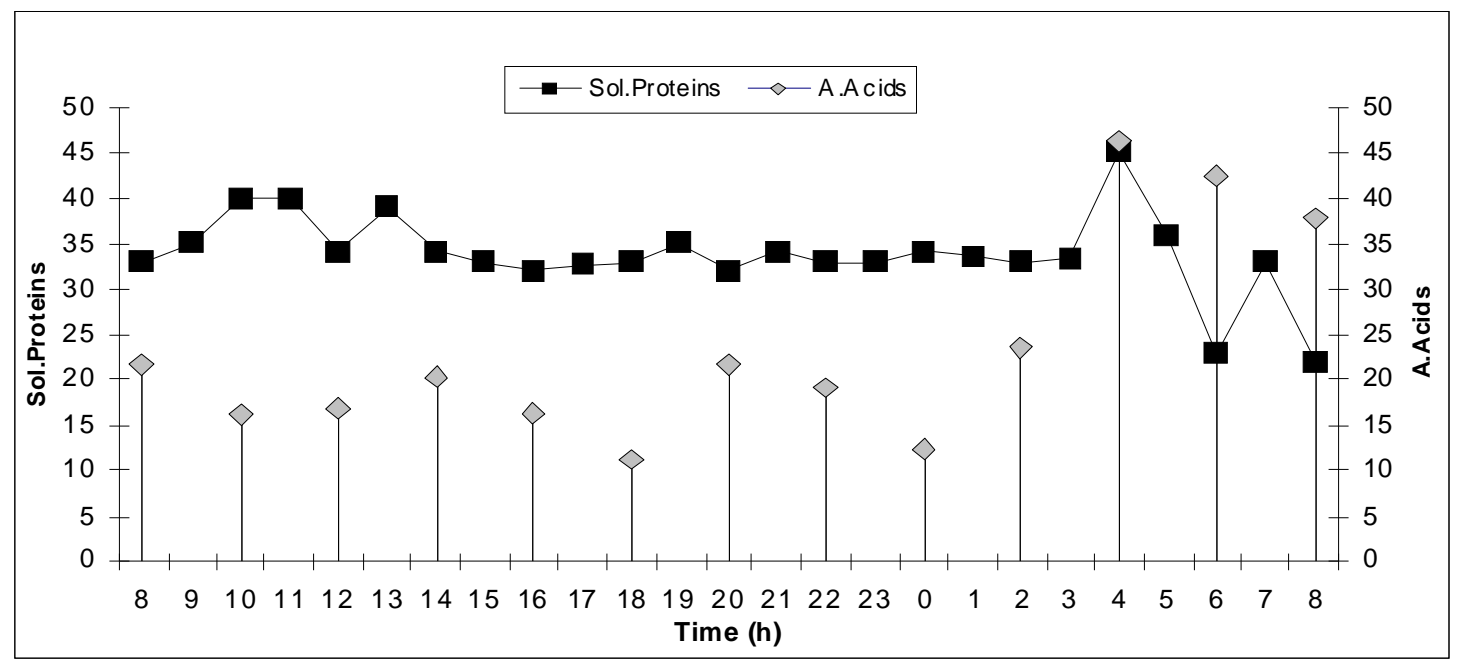

C. M uscle soluble proteins $\mathrm{v} / \mathrm{s}$ amino acids ( $\mathrm{mg} / \mathrm{g}$ ) in Vinstar under D D.

Fig. 5. Circadian changes in profiles of soluble proteins and free amino acids in the skel etal muscle of the fifth instar larva of Bombyx mori, under three photoperiodic conditions, viz., (A) $12 \mathrm{hr}$ light: $12 \mathrm{hr}$ dark cycle (LD), (B): continuous light and (C) continuous dark (DD) conditions. The values expressed in mg per gm-wet weight of tissue, represent $24 \mathrm{hr}$ (8 AM on day-5 to 8A.M on day 6) free running time of the circadian rhythm. 
Table 1. Interval between peaks (elevated points) of protein levels in the muscle of the fourth instar larva of Bombyx mori during the free running period of the rhythm under $12 \mathrm{hr}$ light / dark cycle (LD); continuous light (LL) and continuous dark (DD) conditions.

\begin{tabular}{|c|c|c|c|c|c|c|c|c|c|c|}
\hline \multirow[t]{2}{*}{ Protein type } & \multirow{2}{*}{$\begin{array}{l}\text { Photo- } \\
\text { period }\end{array}$} & \multirow{2}{*}{$\begin{array}{l}\text { No. of } \\
\text { peaks }\end{array}$} & \multicolumn{7}{|c|}{ Inter val between peaks in hours } & \multirow{2}{*}{$\begin{array}{l}\text { M ean interval in } \\
\text { hours }\end{array}$} \\
\hline & & & $1-2$ & $2-3$ & $3-4$ & $4-5$ & $5-6$ & $6-7$ & $7-8$ & \\
\hline \multirow{3}{*}{$\begin{array}{l}\text { Total } \\
\text { Proteins }\end{array}$} & LD & 5 & 6 & 2 & 8 & 4 & - & - & - & 4.0 \\
\hline & LL & 6 & 3 & 5 & 8 & 4 & 3 & - & - & 3.8 \\
\hline & DD & 8 & 2 & 2 & 2 & 6 & 4 & 3 & 4 & 2.9 \\
\hline \multirow{3}{*}{$\begin{array}{l}\text { Soluble } \\
\text { proteins }\end{array}$} & LD & 5 & 4 & 5 & 6 & 4 & - & - & - & 3.8 \\
\hline & LL & 6 & 3 & 4 & 2 & 4 & 7 & - & - & 3.3 \\
\hline & DD & 7 & 2 & 2 & 8 & 4 & 3 & 4 & - & 3.3 \\
\hline \multirow{3}{*}{$\begin{array}{l}\text { Structural } \\
\text { Proteins }\end{array}$} & LD & 6 & 4 & 3 & 2 & 3 & 9 & - & - & 3.5 \\
\hline & LL & 8 & 5 & 3 & 3 & 2 & 3 & 4 & 3 & 2.9 \\
\hline & DD & 7 & 5 & 2 & 3 & 5 & 5 & 4 & - & 3.4 \\
\hline
\end{tabular}

Source: Fig. 1

Table 2. Interval between troughs (low points) of protein levels in the muscle of the fourth instar larva of Bombyx mori during the free running period of the rhythm under $12 \mathrm{~h}$ light / dark cycle (LD); continuous light (LL) and continuous dark (DD)conditions.

\begin{tabular}{|c|c|c|c|c|c|c|c|c|c|c|}
\hline \multirow[t]{2}{*}{ Protein type } & \multirow{2}{*}{$\begin{array}{l}\text { Photo- } \\
\text { period }\end{array}$} & \multirow{2}{*}{$\begin{array}{l}\text { No. of } \\
\text { troughs }\end{array}$} & \multicolumn{7}{|c|}{ Interval between troughs in hours } & \multirow{2}{*}{$\begin{array}{c}\text { M ean interva } \\
\text { in hours }\end{array}$} \\
\hline & & & $1-2$ & $2-3$ & $3-4$ & $4-5$ & $5-6$ & 6-7 & $7-8$ & \\
\hline \multirow{3}{*}{$\begin{array}{l}\text { Total } \\
\text { proteins }\end{array}$} & LD & 5 & 2 & 6 & 5 & 5 & - & - & - & 3.6 \\
\hline & LL & 6 & 5 & 6 & 6 & 4 & 2 & - & - & 3.8 \\
\hline & DD & 8 & 2 & 2 & 5 & 2 & 4 & 3 & 4 & 2.8 \\
\hline \multirow{3}{*}{$\begin{array}{l}\text { Soluble } \\
\text { proteins }\end{array}$} & LD & 7 & 4 & 4 & 4 & 2 & 5 & 5 & - & 3.4 \\
\hline & LL & 6 & 4 & 3 & 4 & 6 & 6 & - & - & 3.8 \\
\hline & DD & 7 & 2 & 2 & 6 & 5 & 3 & 4 & - & 3.1 \\
\hline \multirow{3}{*}{$\begin{array}{l}\text { Structural } \\
\text { proteins }\end{array}$} & LD & 6 & 4 & 2 & 3 & 7 & 5 & - & & 3.5 \\
\hline & LL & 8 & 4 & 3 & 3 & 2 & 3 & 5 & 2 & 2.8 \\
\hline & DD & 7 & 2 & 2 & 3 & 5 & 4 & 4 & - & 2.9 \\
\hline
\end{tabular}

\section{Source: Fig.1}

and 7 troughs in the structural protein rhythm during the $24 \mathrm{hr}$ free running period. Peaks appeared at $08 \mathrm{hr}$ ( 29 mg), $13 \mathrm{hr}$ ( 32 mg), $15 \mathrm{hr}(\sim 30 \mathrm{mg}), 18 \mathrm{hr}(\sim 24 \mathrm{mg})$, $23 \mathrm{hr}(26 \mathrm{mg})$ and next day again at $04 \mathrm{hr}(\sim 25 \mathrm{mg})$ and 08 $\mathrm{hr}(\sim 17 \mathrm{mg})$. Troughs were observed at $10 \mathrm{hr}(\sim 16 \mathrm{mg})$, $12 \mathrm{hr}(\sim 19 \mathrm{mg}), 14 \mathrm{hr}(\sim 23 \mathrm{mg}), 17 \mathrm{hr}(10 \mathrm{mg}), 22 \mathrm{hr}(\sim 14$ $\mathrm{mg})$ and next day at $02 \mathrm{hr}(11 \mathrm{mg})$ and $06 \mathrm{hr}(\sim 15 \mathrm{mg})$.

A mino acid rhythm (Fig. 3A): In the fourth instar larva, the free amino acid (FAA) rhythm of SM maintained relatively higher levels under LL and DD conditions compared to LD. Under LD, the FAA levels ranged from $\sim 7$ to $20 \mathrm{mg}$ with 4 peaks and 4 troughs. Peaks appeared at $10 \mathrm{hr}(\sim 10 \mathrm{mg}), 18 \mathrm{hr}(\sim 19 \mathrm{mg})$ and next day at $02 \mathrm{hr}(\sim$ $20 \mathrm{mg})$ and $06 \mathrm{hr}(14 \mathrm{mg})$ and troughs at $12 \mathrm{hr}(\sim 7 \mathrm{mg}), 22$ $\mathrm{hr}(\sim 11 \mathrm{mg})$, and next day again at $04 \mathrm{hr}(\sim 13 \mathrm{mg})$ and 08 $\mathrm{hr}(\sim 9 \mathrm{mg})$. Under LL, the FAA levels ranged from $\sim 21$ to $\sim 40 \mathrm{mg}$ during the free running time, with 4 peaks and 4 troughs. Peaks occurred at $12 \mathrm{hr}(\sim 40 \mathrm{mg}), 16 \mathrm{hr}(\sim 38$ $\mathrm{mg})$ and $20 \mathrm{hr}(\sim 37 \mathrm{mg})$ and next day at $08 \mathrm{hr}(30 \mathrm{mg})$, while troughs were recorded at $08 \mathrm{hr}(\sim 33 \mathrm{mg}), 14 \mathrm{hr}(\sim 24$ $\mathrm{mg}), 00 \mathrm{hr}(\sim 26 \mathrm{mg})$ and again next day at 04-06 hr ( 20 mg each). Under DD, the rhythm lies in between those of LD and LL, with FAA values ranging from $~ 17$ to $44 \mathrm{mg}$. Further, the rhythm recorded 4 peaks and 3 troughs during the free running time. Peaks occurred at $18 \mathrm{hr}(\sim 35 \mathrm{mg}) 22$ $\mathrm{hr}(\sim 33 \mathrm{mg}), 02 \mathrm{hr}(\sim 37 \mathrm{mg})$ and again next day at $08 \mathrm{hr}$ $(\sim 44 \mathrm{mg})$ and troughs were reported at $08 \mathrm{hr}(\sim 17 \mathrm{mg}), 20$ $\mathrm{hr}(\sim 26 \mathrm{mg})$ next day at $06 \mathrm{hr}(\sim 23 \mathrm{mg})$.

Fifth instar larval rhythms

Total protein rhythm (Fig. 2A; Tables 3 and 4): In the fifth instar larva, the total protein rhythm of SM showed 6 peaks and 6 troughs. Peaks appeared at $9 \mathrm{hr}(\sim 69 \mathrm{mg}), 13$ $\mathrm{hr}(\sim 71 \mathrm{mg}), 17 \mathrm{hr}(\sim 61 \mathrm{mg}), 21 \mathrm{hr}(\sim 97 \mathrm{mg})$ and next day again at $01 \mathrm{hr}(\sim 77 \mathrm{mg})$ and $03 \mathrm{hr}(\sim 67 \mathrm{mg})$. Troughs occurred at $12 \mathrm{hr}$ ( 44 mg), $14 \mathrm{hr}(\sim 50 \mathrm{mg}), 19 \mathrm{hr}(\sim 44 \mathrm{mg})$, $00 \mathrm{hr}$ (33 mg), $02 \mathrm{hr}(42 \mathrm{mg})$ and $08 \mathrm{hr}$ ( 48 mg). Under LL, the total protein rhythm recorded 5 peaks and 5 troughs. Peaks were recorded at $08 \mathrm{hr}(\sim 62 \mathrm{mg}), 15 \mathrm{hr}(74 \mathrm{mg}), 20 \mathrm{hr}$ $(\sim 62 \mathrm{mg})$ and next day at $01 \mathrm{hr}(\sim 54 \mathrm{mg})$ and $05-06 \mathrm{hr}(\sim 71$ mg each). Troughs, were observed at 10-12 hr (41-43 mg), $16-19 \mathrm{hr}(\sim 39-40 \mathrm{mg}), 21-23 \mathrm{hr}(\sim 42-45 \mathrm{mg})$ and next day at $02 \mathrm{hr}(49 \mathrm{mg})$ and $08 \mathrm{hr}(\sim 47 \mathrm{mg})$. Similarly, the phase 
Table 3. Interval between peaks (elevated points) of protein levels in the muscle of fifth instar larva of Bombyx mori during the free running period of the rhythm under $12 \mathrm{hr}$ light $/ 2 \mathrm{~h}$ dark cycle (LD); continuous light (LL) and continuous dark (DD) conditions.

\begin{tabular}{lcccccccccc}
\hline \multirow{2}{*}{ Protein type } & Photo- & No. of & \multicolumn{7}{c}{ nterval between peaks in hours } & Mean interval in \\
& period & peaks & $1-2$ & $2-3$ & $3-4$ & $4-5$ & $5-6$ & $6-7$ & hours \\
\hline Total & LD & 6 & 4 & 4 & 4 & 4 & 2 & - & 3.0 \\
proteins & LL & 5 & 7 & 5 & 5 & 5 & - & - & 4.4 \\
& DD & 6 & 3 & 6 & 2 & 3 & 4 & - & 3.0 \\
Soluble & LD & 7 & 2 & 3 & 4 & 5 & 5 & 3 & 3.1 \\
proteins & LL & 7 & 5 & 2 & 3 & 3 & 5 & 5 & 3.3 \\
& DD & 7 & 2 & 6 & 2 & 3 & 4 & 3 & 2.9 \\
Structural & LD & 6 & 4 & 8 & 4 & 4 & 2 & - & 3.6 \\
proteins & LL & 6 & 6 & 6 & 5 & 4 & 3 & - & 4.0 \\
& DD & 7 & 3 & 6 & 2 & 3 & 4 & 2 & 2.9 \\
\hline
\end{tabular}

Source: Fig. 2

Table 4. Interval between troughs (low points) of protein levels in the muscle of fifth instar larva of Bombyx mori during the free running period of the rhythm under $12 \mathrm{hr}$ light / $12 \mathrm{hr}$ dark cycle (LD); continuous light (LL) and continuous dark (DD)conditions.

\begin{tabular}{llccccccccc}
\hline \multirow{2}{*}{ Protein type } & P hoto- & No. of & \multicolumn{7}{c}{ Inter val between tr oughs in hours } & M ean interval \\
& period & troughs & $1-2$ & $2-3$ & $3-4$ & $4-5$ & $5-6$ & $6-7$ & in hours \\
\hline Total & LD & 6 & 2 & 5 & 5 & 2 & 6 & - & 3.3 \\
proteins & LL & 5 & 7 & 4 & 3 & 6 & - & - & 4.0 \\
& DD & 7 & 4 & 4 & 4 & 3 & 3 & 6 & 3.4 \\
Soluble & LD & 7 & 2 & 3 & 5 & 7 & 3 & 3 & 3.3 \\
proteins & LL & 7 & 3 & 2 & 4 & 3 & 6 & 3 & 3.0 \\
& DD & 7 & 4 & 4 & 4 & 3 & 7 & 2 & 3.4 \\
Structural & LD & 7 & 4 & 4 & 8 & 3 & 3 & 2 & 3.4 \\
proteins & LL & 5 & 7 & 4 & 3 & 5 & - & - & 3.8 \\
& DD & 7 & 3 & 5 & 4 & 3 & 3 & 5 & 3.3 \\
\hline
\end{tabular}

\section{Source: Fig.2}

response curve of the total protein rhythm recorded 6 peaks and 7 troughs under continuous dark (DD) condition. Peaks occurred at $10 \mathrm{hr}(\sim 61 \mathrm{mg}), 13 \mathrm{hr}(\sim 66$ $\mathrm{mg}), 19 \mathrm{hr}(\sim 75 \mathrm{mg}), 21 \mathrm{hr}(\sim 67 \mathrm{mg}), 00 \mathrm{hr}(66 \mathrm{mg})$ and again, next day at $04 \mathrm{hr}(\sim 84 \mathrm{mg})$. Troughs appeared at 08 $\mathrm{hr}(\sim 51 \mathrm{mg}), 11-12 \mathrm{hr}(57-59 \mathrm{mg}), 16 \mathrm{hr}(\sim 44 \mathrm{mg}), 20 \mathrm{hr}(\sim 54$ $\mathrm{mg}), 23 \mathrm{hr}$ ( 48 mg), $02 \mathrm{hr}(\sim 51 \mathrm{mg}) 08 \mathrm{hr}(43 \mathrm{mg})$.

Soluble protein rhythm (Fig. 2 B; Tables 3 and 4): Under $\mathrm{LD}$, the muscle soluble protein rhythm showed 7 peaks and 7 troughs during its free running time. Peaks appeared at $08 \mathrm{hr}(\sim 41 \mathrm{mg}), 10 \mathrm{hr}(\sim 35 \mathrm{mg}), 13 \mathrm{hr}(\sim 43 \mathrm{mg}), 17 \mathrm{hr}(\sim 45$ $\mathrm{mg}), 22 \mathrm{hr}(\sim 50 \mathrm{mg})$ and next day at $03 \mathrm{hr}(\sim 43 \mathrm{mg})$ and 06 $\mathrm{hr}(\sim 36 \mathrm{mg})$. Troughs occurred at $09 \mathrm{hr}(\sim 24 \mathrm{mg}), 11 \mathrm{hr}$ $(\sim 30 \mathrm{mg}), 14 \mathrm{hr}(\sim 25 \mathrm{mg}), 19 \mathrm{hr}(\sim 26 \mathrm{mg})$ and $00-02 \mathrm{hr}(\sim 20-$ $21 \mathrm{mg}), 05 \mathrm{hr}(\sim 25 \mathrm{mg})$ and $08 \mathrm{hr}(\sim 27 \mathrm{mg})$. Under LL, the soluble protein profiles of the muscle showed 7 peaks and 7 troughs. Peak appeared at $08 \mathrm{hr}(\sim 34 \mathrm{mg}), 13 \mathrm{hr}$ $(\sim 32 \mathrm{mg}), 15 \mathrm{hr}(\sim 36 \mathrm{mg}), 18 \mathrm{hr}(\sim 26 \mathrm{mg})$, and $21 \mathrm{hr}(\sim 30$ $\mathrm{mg})$ and next day at $02 \mathrm{hr}(\sim 34 \mathrm{mg})$ and $07 \mathrm{hr}(\sim 32 \mathrm{mg})$. Troughs were recorded at $11 \mathrm{hr}(\sim 29 \mathrm{mg}), 14 \mathrm{hr}(\sim 27 \mathrm{mg})$, $16 \mathrm{hr}(\sim 20 \mathrm{mg}), 20 \mathrm{hr}(\sim 14 \mathrm{mg}), 23 \mathrm{hr}(\sim 27 \mathrm{mg})$ and next day at $05 \mathrm{hr}(\sim 29 \mathrm{mg})$ and $08 \mathrm{hr}(\sim 28 \mathrm{mg})$. Under DD, the phase response curve of the soluble protein rhythm showed 7 peaks and 7 troughs. Peak occurred at $10 \mathrm{hr}$ (40 $\mathrm{mg}), 13 \mathrm{hr}(\sim 39 \mathrm{mg}), 19 \mathrm{hr}(\sim 35 \mathrm{mg}), 21 \mathrm{hr}(\sim 34 \mathrm{mg}), 00 \mathrm{hr}$ $(\sim 34 \mathrm{mg})$ and next day at $04 \mathrm{hr}(\sim 45 \mathrm{mg})$ and $07 \mathrm{hr}(\sim 33$ $\mathrm{mg})$. The troughs under DD appeared at $08 \mathrm{hr}(\sim 33 \mathrm{mg})$, $12 \mathrm{hr}(\sim 34 \mathrm{mg}), 16 \mathrm{hr}(\sim 32 \mathrm{mg}), 20 \mathrm{hr}(\sim 32 \mathrm{mg}), 22-23 \mathrm{hr}$ $(\sim 33 \mathrm{mg}$ each) and next day at $06 \mathrm{hr}(23 \mathrm{mg})$ and $08 \mathrm{hr}(\sim 22$ $\mathrm{mg})$.

Structural protein rhythm (Fig. 2 C; Tables 3 and 4): The phase response curve of structural protein rhythm showed 6 peaks and 7 troughs under LD. Peaks appeared at $09 \mathrm{hr}(\sim 45 \mathrm{mg}), 13 \mathrm{hr}(\sim 28 \mathrm{mg}), 21 \mathrm{hr}(\sim 50 \mathrm{mg})$ and next day at $01 \mathrm{hr}(\sim 49 \mathrm{mg}), 04-05 \mathrm{hr}(\sim 33 \mathrm{mg})$ and $07 \mathrm{hr}(\sim 29$ $\mathrm{mg})$. Troughs were observed at $08 \mathrm{hr}(\sim 23 \mathrm{mg}), 12 \mathrm{hr}(\sim 9$ $\mathrm{mg}), 16 \mathrm{hr}(\sim 10 \mathrm{mg}), 00 \mathrm{hr}(\sim 11 \mathrm{mg})$ and next day at $02 \mathrm{hr}$ $(\sim 22 \mathrm{mg}), 06 \mathrm{hr}(22 \mathrm{mg})$ and $08 \mathrm{hr}(\sim 21 \mathrm{mg})$. Under LL, 6 peaks and 5 troughs were observed in the structural protein rhythm. Peaks appeared at $08 \mathrm{hr}(\sim 27 \mathrm{mg}), 14 \mathrm{hr}$ $(\sim 41 \mathrm{mg}), 20 \mathrm{hr}(\sim 49 \mathrm{mg})$ and next day at $01 \mathrm{hr}(\sim 23 \mathrm{mg})$, $05 \mathrm{hr}(\sim 42 \mathrm{mg})$ and $08 \mathrm{hr}(\sim 20 \mathrm{mg})$. Troughs appeared at 
Table 5. Comparative analysis of the phase response curves of the protein rhythm in the muscle of the fourth and fifth instar larvae of Bombyx mori, in terms of mean number of peaks and troughs and the mean interval between them, under $12 \mathrm{~h}$ light / dark cycle (LD), continuous light (LL) and continuous dark (DD) conditions. The rhythm under LD was treated as control for both fourth and fifth instars and for computing the free running time of the protein rhythm.

\begin{tabular}{|c|c|c|c|c|c|c|}
\hline \multirow[t]{2}{*}{ Parameter } & \multicolumn{3}{|c|}{ F ourth instar } & \multicolumn{3}{|c|}{ Fifth instar } \\
\hline & $\begin{array}{c}\text { LD } \\
\text { (C ontrol) }\end{array}$ & $L L$ & DD & $\begin{array}{c}\text { LD } \\
\text { (Control) }\end{array}$ & LL & DD \\
\hline Average number of peaks & 5.3 & $\sim 6.3$ & $\sim 7.3$ & $\sim 6.3$ & 6 & $\sim 6.7$ \\
\hline Average number of troughs & 6 & $\sim 9$ & $\sim 8$ & $\sim 6.7$ & 5.7 & 7 \\
\hline $\begin{array}{l}\text { Mean interval between } \\
\text { peaks }\end{array}$ & $\sim 3.8 \mathrm{hr}$ & $\sim 3.3 \mathrm{hr}$ & $2.7 \mathrm{hr}$ & $\sim 3.2 \mathrm{hr}$ & $3.9 \mathrm{hr}$ & $\sim 2.9 \mathrm{hr}$ \\
\hline $\begin{array}{l}\text { Mean interval between } \\
\text { troughs }\end{array}$ & $3.5 \mathrm{hr}$ & $3.5 \mathrm{hr}$ & $2.9 \mathrm{hr}$ & $\sim 3.3 \mathrm{hr}$ & $3.6 \mathrm{hr}$ & $\sim 3.4 \mathrm{hr}$ \\
\hline $\begin{array}{l}\text { Combined mean interval of } \\
\text { peaks }+ \text { troughs }\end{array}$ & $\sim 3.7 \mathrm{hr}$ & $3.4 \mathrm{hr}$ & $3.6 \mathrm{hr}$ & $\sim 3.3 \mathrm{hr}$ & $\sim 3.8 \mathrm{hr}$ & $\sim 3.2 \mathrm{hr}$ \\
\hline $\begin{array}{l}\text { Probable no. of protein } \\
\text { synthetic cycles (Mean of } \\
\text { peaks + troughs) }\end{array}$ & $\sim 6$ & $\sim 8$ & $\sim 8$ & $\sim 7$ & $\sim 6$ & $\sim 7$ \\
\hline $\begin{array}{l}\text { Time taken for each PS } \\
\text { cycle }\end{array}$ & $\begin{array}{c}4 \mathrm{hr} \\
(24 /=6)\end{array}$ & $\begin{array}{c}3 \mathrm{hr} \\
(24 / 8=3)\end{array}$ & $\begin{array}{c}3 \mathrm{hr} \\
(24 / 8=3)\end{array}$ & $\begin{array}{c}\sim 3.4 \\
(24 / 7=3.4)\end{array}$ & $\begin{array}{c}\sim 4 \mathrm{hr} \\
(24 / 6=4)\end{array}$ & $\begin{array}{c}\sim 3.4 \\
(24 / 7=3.4)\end{array}$ \\
\hline $\begin{array}{l}\text { Free running time of the } \\
\text { rhythm }\end{array}$ & $\begin{array}{c}\sim 24 \mathrm{hr} \\
(6 \times 4=24)\end{array}$ & $\begin{array}{c}\sim 18 \mathrm{hr} \\
(6 \times 3=18)\end{array}$ & $\begin{array}{c}\sim 18 \mathrm{hr} \\
(6 \times 3=18)\end{array}$ & $\begin{array}{c}\sim 24 \mathrm{hr} \\
(7 \times 3.4=23.8)\end{array}$ & $\begin{array}{c}\sim 28 \mathrm{hr} \\
(7 \times 4=28)\end{array}$ & $\begin{array}{c}\sim 24 \mathrm{hr} \\
(7 \times 3.4=28)\end{array}$ \\
\hline
\end{tabular}

Source: Figs. 1 and 2; Tables 1, 2, 3 and 4.

$10-12 \mathrm{hr}$ ( $10-11 \mathrm{mg}), 18-19 \mathrm{hr}$ ( $13 \mathrm{mg}$ each), 22-23 hr $(\sim 15 \mathrm{mg}$ each $)$ and next day at $02 \mathrm{hr}(\sim 16 \mathrm{mg})$ and $07 \mathrm{hr}$ $(\sim 14 \mathrm{mg})$. Under DD, the structural protein rhythm displayed 7 peaks and 7 troughs. As regards the peaks, they appeared at $10 \mathrm{hr}(\sim 21 \mathrm{mg}), 13 \mathrm{hr}(\sim 28 \mathrm{mg}), 19 \mathrm{hr}(\sim 40$ $\mathrm{mg}), 21 \mathrm{hr}(\sim 33 \mathrm{mg}), 00 \mathrm{hr}(\sim 32 \mathrm{mg})$ and next day at $04 \mathrm{hr}$ $(\sim 40 \mathrm{mg})$ and again at $06 \mathrm{hr}(\sim 29 \mathrm{mg})$, while troughs occurred at $08 \mathrm{hr}(\sim 18 \mathrm{mg}), 11 \mathrm{hr}(\sim 17 \mathrm{mg}), 16 \mathrm{hr}(\sim 12 \mathrm{mg})$, $20 \mathrm{hr}(\sim 23 \mathrm{mg}), 23 \mathrm{hr}(\sim 15 \mathrm{mg})$ and next day at $02 \mathrm{hr}(\sim 18$ $\mathrm{mg})$ and $07 \mathrm{hr}(\sim 19 \mathrm{mg})$.

Free amino acid rhythm (Fig. 3 B): The fifth instar circadian amino acid rhythm differs slightly from that of the fourth instar. Barring a few exceptions, significantly an elevated rhythm with relatively higher levels of free amino acids ( $\sim 17 \mathrm{mg}$ to $\sim 42 \mathrm{mg}$ ) was recorded under $\mathrm{LD}$ compared to that of LL ( $\sim 14 \mathrm{mg}$ to $41 \mathrm{mg})$ and DD $(\sim 11$ $\mathrm{mg} 46 \mathrm{mg}$ ). The LD condition caused 4 peaks and 4 troughs in the PRC of the amino acid rhythm, with peaks at $18 \mathrm{hr}(\sim 42 \mathrm{mg}), 22 \mathrm{hr}(\sim 31 \mathrm{mg}), 02 \mathrm{hr}(\sim 37 \mathrm{mg})$ and $06 \mathrm{hr}$ $(\sim 35 \mathrm{mg})$ and troughs at $10 \mathrm{hr}(\sim 17 \mathrm{mg}), 20 \mathrm{hr}(\sim 18 \mathrm{mg}), 00$ $\mathrm{hr}(\sim 19 \mathrm{mg}), 04 \mathrm{hr}(\sim 23 \mathrm{mg})$ and $08 \mathrm{~h}(\sim 20 \mathrm{mg})$. Under LL, free amino acid rhythm recorded 5 peaks and 5 troughs. While peaks occurred at $08 \mathrm{~h}(\sim 19 \mathrm{mg}), 14 \mathrm{hr}(\sim 41 \mathrm{mg}), 20$ $\mathrm{hr}(\sim 20 \mathrm{mg}), 02 \mathrm{hr}(25 \mathrm{mg})$ and again at $06 \mathrm{hr}(\sim 35 \mathrm{mg})$, the troughs occurred at $10 \mathrm{hr}(\sim 13 \mathrm{mg}), 18 \mathrm{hr}(\sim 14 \mathrm{mg}), 22 \mathrm{hr}$ $(\sim 18 \mathrm{mg})$ and next day at $04 \mathrm{hr}(23 \mathrm{mg})$ and $08 \mathrm{hr}(\sim 24 \mathrm{mg})$. Under DD, the amino acid rhythm recorded 4 peaks and 4troughs. The peaks were observed at $08 \mathrm{hr}(\sim 22 \mathrm{mg}), 14$ $\mathrm{hr}(\sim 20 \mathrm{mg}), 20 \mathrm{hr}(\sim 22 \mathrm{mg})$ and next day at $04 \mathrm{hr}(\sim 46 \mathrm{mg})$, while the troughs were observed at $10 \mathrm{hr}(\sim 16 \mathrm{mg}) 18 \mathrm{hr}$ $(\sim 11 \mathrm{mg}), 00 \mathrm{hr}(\sim 12 \mathrm{mg})$ and next day at $08 \mathrm{~h}(\sim 38 \mathrm{mg})$. The PRCs of protein and amino acid rhythms showed some minor ups and downs in protein and amino acid profiles that are not statistically significant to be counted as peaks and troughs under all the three photoperiodic conditions (LD, LL and DD) in both the larval instars examined.

\section{DISCUSSION}

The muscle of $B$. mori represents the chief contractile machinery that develops in a stage-specific manner up to the larval stage and atrophies in pupal and adult stages except for the flight muscles. The proteome profiles of muscle in silkworm, revealed the presence of at least 258 proteins that may include 57 larval and 54 pupal proteins, twelve of which belong to the contractile apparatus, metabolism, regulation and signal transduction other unidentified proteins (Zhang et al., 2007). Their levels rise and fall in a rhythmic fashion during the $24 \mathrm{hr}$ free running time and appear in the form of peaks and troughs in the phase response curves (Figs. 1 and 2). As reported in our previous reports for the silk gland and the fat body (Sailaja and Sivaprasad, 2010 a, 2010 b, 2011), the peaks and troughs in the phase response curves (PRCs) of the skeletal muscle protein rhythm probably indicates two vital stages of gene expression; translation (protein synthesis) and transcription, and the combined mean interval between a peak and trough reflects the duration 
of each protein synthetic cycle (PS cycle). The present study demonstrates that the number of PS cycles varies in instar-specific and photoperiod-specific fashions in B. mori with alternating transcriptional and translational phases.

Instar-specific clock shifting: The analysis of the phase response curves of the protein rhythms of the fourth and fifth instar stages under normal LD conditions, clearly reflect variation in the number of PS cycles vis-àvis the duration of free running time of the protein rhythm. The number of PS cycles increased from $\sim 6$ to $\sim 7$ when the larva developed from fourth to fifth larval stage. At the same time, the duration of each cycle is declined from 4 to $3.4 \mathrm{hr}$ (Table 5), indicating a higher rate of protein synthesis during fifth instar, compared to fourth instar. This difference obviously occurs due to the acceleration in fifth instar, the rate of each PS cycle by $0.6 \mathrm{hr}$ ( or $36 \mathrm{~m}$ ) with consequent advancement of the free running time of the $24 \mathrm{hr}$-fourth instar rhythm to $20 \mathrm{hr}$ in the fifth instar. Though, it is not possible to attribute any tangible reason for the shift of this magnitude in the protein rhythm, it appears to be instar-specific and timedependent. Clearly, the fourth instar with shorter duration (4 days) of larval life has a higher rhythmic rate, while the fifth instar with longer duration ( 7 to 8 days) of larval life maintains a high rate of muscle protein rhythm, with increased number of PS cycles. Notably, during the free running time of the muscle protein rhythm the fourth instar larva accomplishes $6 \times 4=24$ cycles, where as the fifth instar larva completes either $49(7 \times 7)$ or $56(7 \times 8)$ cycles, resulting in the operation of 25 or 32 additional PS cycles, a fact that reflects two possibilities.

Synthesis of additional proteins that commensurate with the fifth instar larval growth and development as evidenced by the prevalence of higher peaks in the protein profiles of fifth instar larva, compared to those of fourth instar (Figs. 1 and 2). These could include several metabolic enzymes such as aldose reductase, glyoxylate reductase, hydroxyl pyruvate isomerase and amino acylase and proteins such as troponin and immunoblotting validation which appear in fifth instar and accumulate in silkworm tissues through pupal stage and help in energy metabolism during pupal-adult metamorphosis (Hou et al., 2010). Though, these proteins are not individually identified, their higher levels, nevertheless support the view that additional proteins are synthesized in silkworm tissues in a stage-specific fashion during metamorphosis.

Recruitment of additional genes that specifically express during fifth instar development adding new proteins from time to time in a circadian fashion. It is not known as to which genes are expressed and which proteins are synthesized during fourth and fifth instars. But, the indications are that the two silk genes; sericin- 2 and fibroin, express actively during fourth and fifth instars respectively (Ishikawa and Suzuki, 1985; Michaille et al., 1989). In a similar fashion, ten fat body genes express in a stage-specific way to produce a genetically variable group of lipoproteins that play vital role in energy metabolism during embryonic development in silkworm (Hou et al., 2010). A similar pattern of gene expression might operate in the silkworm muscle tissue as well. Thus, the instar-specific clock shifting of circadian protein rhythm in the muscle probably involves changes in the rate and the timing of tissue-specific gene expression or both, a point that needs further investigations.

Photoperiod-specific clock shifting: The impact of light as the principal zeitgeber (time giver) of the circadian clock mechanism in Drosophila, is well known (Peschel et al., 2009). The present trends are consistent with our earlier findings (Sailaja and Sivaprasad, 2010 a, b, 2011). Obviously, the circadian protein rhythms in B. mori are subjected to clock-shifting or entrainment by the light cues under altered photoperiodic conditions (viz., LD, LL and DD) and this results in changing the number and duration of PS cycles in the silkworm larvae. Accordingly, when the growing silkworm larvae are deprived of natural light cues (12 hr light and $12 \mathrm{hr}$ dark condition) the free running time of the circadian protein rhythm shifts from the standard $24 \mathrm{hr}$-pattern in a stage-specific fashion. In the fourth instar, the rhythm maintained 6 PS cycles under LD, 8 each under LL and DD, with varying durations under the three photoperiodic conditions. It is about $4 \mathrm{hr}$ under LD, $3 \mathrm{hr}$ each under LL and DD. Thus, in the fourth instar larvae, both LL and DD conditions reset the normal protein rhythm ahead of the free running time exactly by six hours @ one hour per each PS cycle. Consequently, the $24 \mathrm{hr}$ free running time of the rhythm under LD is re-scheduled to operate at $18 \mathrm{hr}$ under LL and DD (Table 5).

In the fifth instar, the impact of the light on the protein rhythm is still more pronounced. While 7 PS cycles were maintained under LD, it decreased by one cycle (to 6 cycles) under LL, but increased to 7 cycles under DD. At the same time, the duration of each cycle stood at $\sim 3.4 \mathrm{hr}$ under LD, $4 \mathrm{hr}$ under LL and $3.4 \mathrm{hr}$ under DD (Table 5). Thus, the duration of each cycle of protein rhythm is increased by $0.6 \mathrm{hr}$ or $36 \mathrm{~m}$ (from 3.4 to $4 \mathrm{hr}$ ) under LL, but remained the same $(3.4 \mathrm{hr}$ ) under $\mathrm{DD}$, resulting in clockshifting the $24 \mathrm{hr}$ free running time of the rhythm under LD to $28 \mathrm{hr}$ under LL, but maintained at the same level, i.e., $24 \mathrm{hr}$ under DD condition.

As reported in our earlier findings (Sailaja and Sivaprasad, $2010 \mathrm{a}, \mathrm{b}, 2011$ ) the photoperiod- induced clock-shift in protein rhythm reflects similar phase-shift in gene expressions in the silkworm muscle tissue. Presumably, in the fourth instar, the genes express $\sim 6$ times under LD (with $3.7 \mathrm{hr}$ intervals), 8 times each under LL and DD 
(with $\sim 3.5 \mathrm{hr}$ intervals), while in fifth instar they express 7 times under LD (with $3.3 \mathrm{hr}$ intervals), 6 times under LL (with $3.8 \mathrm{hr}$ intervals) and 7 times under DD (with $3.2 \mathrm{hr}$ intervals). Though, one-to-one relationship between light and gene expression timing is not available, the circadian clock mechanism observed in Drosophila and other insects point to this fact (Hall, 2003; Syrova et al., 2003; Grima et al., 2004; Shafer et al., 2004; Stoleru et al., 2004). Nonetheless, the positive impact of light on muscle protein synthesis in the silkworm is demonstrated more clearly during fourth instar than in fifth instar.

Protein rhythm ver sus fr ee amino acids: Since, the free amino acid (FAA) profiles in silkworm tissues fluctuate with changes in the rate of protein synthesis; the protein rhythm varies as a function of their reserves (Sailaja and Sivaprasad, 2011). Since, the nascent proteins are freely available in the form of soluble proteins; a comparative analysis of the phase response curves of these two biochemical constituents facilitates meaningful conclusions with regard to the instar-specific and photoperiod-specific variations in their rhythms. As shown in figures 4 and 5, the protein synthetic phases (peaks) are preceded by elevations in the levels of free amino acids notwithstanding some minor deviations that are apparently caused by sampling errors.

Under LD, the FAA pool available at a particular hour, is used up either in the same PS cycle or in the subsequent cycles in the next one or two hours. In the fourth instar, for instance, the rise in the levels of FAA at 8-10 h, 12$14 \mathrm{hr}, 16-18 \mathrm{hr}, 20 \mathrm{hr}, 00-02 \mathrm{hr}$ and $04-06 \mathrm{hr}$ on second day are used-up in the PS cycles occurred at 8-10 hr, 13-15 hr, 17-19 hr, $21 \mathrm{hr}, 00-02 \mathrm{hr}$ and 4-6 hr respectively (Fig. 4A). Similarly, in the fifth instar, the elevations in the FAA levels at $8 \mathrm{hr}, 12 \mathrm{hr}, 14-18 \mathrm{hr}, 20-22 \mathrm{hr}, 02 \mathrm{hr}$, and $6 \mathrm{hr}$ were accompanied by peaks in soluble protein levels at 08-10 $\mathrm{hr}, 13 \mathrm{hr}, 16-17 \mathrm{hr}, 21-23 \mathrm{hr}, 3 \mathrm{hr}$ and $6 \mathrm{hr}$ respectively (Fig. $4 \mathrm{~B})$. Thus, the ongoing PS cycles are sustained by free amino acid inputs from time to time during the free running time of the protein rhythm. The situation under LL is slightly different. In both the fourth and fifth instars, the FAA levels at a particular hour are followed by an increase in the levels of soluble proteins, indicating their utilization within one hour after their availability. As shown in the figure $5 \mathrm{~A}$, in the fourth instar, the rise in the FAA levels at $8 \mathrm{hr}, 10 \mathrm{hr}, 14 \mathrm{~h}, 16 \mathrm{~h}, 20 \mathrm{hr}, 22 \mathrm{hr}, 02 \mathrm{hr}$ was proceeded by corresponding increase in the levels of proteins at 8 h, 10-11hr, 14-15 hr, $17 \mathrm{hr}, 21 \mathrm{hr}, 23 \mathrm{hr}$ and 03-04 hr respectively. Similarly, in the fifth instar larval stage, the rise in FAA levels at $08 \mathrm{~h}, 12 \mathrm{~h}, 14 \mathrm{hr}, 16 \mathrm{~h}, 20-02 \mathrm{hr}$ and 06 $\mathrm{h}$, were accompanied by elevation in the soluble protein levels at $08 \mathrm{~h}, 12-13 \mathrm{~h}, 15 \mathrm{hr}, 17-19 \mathrm{hr}, 21-03 \mathrm{hr}$ and $06-07 \mathrm{hr}$ respectively (Fig. $5 \mathrm{~B}$ ).

The conditions under DD are different from those of LD and LL (Figs. $4 \mathrm{C}$ and $5 \mathrm{C}$ ), in which the increase in the levels of FAA at a particular hour were utilized in a disturbed fashion in the next few hours. While, in fourth instar, the increase in the levels of FAA at $08 \mathrm{hr}, 10 \mathrm{hr}, 12$ $\mathrm{hr}, 14-18 \mathrm{hr}, 20-02 \mathrm{hr}, 02 \mathrm{hr}$ and $08 \mathrm{~h}$ was accompanied by similar upsurge in protein levels at $09 \mathrm{~h}, 11 \mathrm{~h}, 13 \mathrm{~h}, 19$ 21hr, 01-07 hr, 04-05 hr and $08 \mathrm{hr}$ respectively. In the fifth instar, the increase in the levels of FAA at $08 \mathrm{hr}, 12 \mathrm{hr}, 14$ $\mathrm{hr}, 20 \mathrm{hr}, 02 \mathrm{hr}, 04 \mathrm{~h}$ and $06 \mathrm{hr}$ was followed by similar elevations in soluble protein levels at 10-11 hr, $13 \mathrm{hr}, 14$ $19 \mathrm{hr}, 21-03 \mathrm{hr}, 02-03 \mathrm{hr}, 04 \mathrm{hr}$ and $07 \mathrm{hr}$ respectively (Fig. 6C).

Clearly, the photoperiod modulates protein rhythm of the skeletal muscle by mobilizing the free amino acids required for protein synthesis from time to time during the free running time of the rhythm as reported in our earlier findings in B. mori (Sailaja and Sivaprasad, 2011). When the silkworms were reared separately, the LL and dark DD conditions advanced the rhythm by favouring quicker utilization of free amino acids in both the instars, but under LD, the light and dark conditions together delayed the operation of protein rhythm by favouring slow utilisation of the amino acid pool. Probably, because of this reason, the number of protein synthetic cycles is increased from 7 to 8 under LL and DD conditions in fourth instar, advancing the free running time of the rhythm by $6 \mathrm{hr}$, thus setting the $24 \mathrm{hr}$ rhythm to operate at $18 \mathrm{hr}$. But in the fifth instar this situation is not true as the number of PS cycles actually declined from 7 under LD to 6 under LL but remained the same under DD condition. This results in delaying the rhythm by $4 \mathrm{hr}$ under LL. Obviously, the muscle protein rhythm, which is active in fourth instar larval stage, runs on a slow note under LL condition in fifth instar; obviously due to priority given to silk protein synthesis in the silk gland during this stage (Sailaja and Sivaprasad, 2010 a, 2010 b). The study demonstrates two points. Firstly, the muscle protein rhythm is slowed down by continuous light cues under LL when the larva moves from fourth to fifth instar and secondly, the darkness (either in LD or DD condition) is essential for the sustenance of muscle protein rhythm during fifth instar development.

\section{REFERENCES}

Colowick, S. P. and Kaplan, N.O. (1957). Methods in Enzymology. Academic Press, New York, 63: 28.

Fukuta, M., Matsuno, K., Hui, C., Nagata, T., Takiya, S., Xu, P. X., Ueno, K. and Suzuki, Y. (1993). Molecular cloning of a POU domain-containing factor involved in the regulation of the Bombyx sericin-1 gene. J . Boil. Chem., 268: 1947119475.

Gizelak, K. (1995). Control of expression of silk protein genes. Comp. Biochem. Physiol. B: Biochem. M ol. Boil., 110: 671681.

Grima, B., Chelot, B.E., Xia, R. and Rouyer, F. (2004). Morning and evening peaks of activity rely on different clock neurons 
of the Drosophila brain. Nature, 431: 862-868.

Hall, J.D. (2003). Genetics and Molecular Biology of Rhythms in Drosophila and other insects. Academic Press, Amsterdam, pp 286.

Hou, Y., Zou, Y., Wang, F., Gong, J., Zhong, X., Xia, Q. and Zhao, P. (2010). Comparative analysis of proteome maps of silkworm haemolymph during different developmental stages. Proteome Sci., 8: 45.

Ishikawa, E. and Suzuki,Y. (1985). Tissue and stage-specific expression of sericin genes in the middle silk gland of Bombyx mori. D ev. G rowth D iff., 27: 73-82.

Iwai, S., Fukui, Y., Fujiwara, Y. and Takeda, M. (2006). Structure and expressions of two circadian clock genes, period and timeless in the commercial silkmoth, Bombyx mori. J . Insect Physiol., 52(6): 625-637.

Kawasaki, F. and Kita, H. (2004). Structure and innervation of longitudinal and transverse abdominal muscles of the cricket Gryllus bimaculatus. J.Comp.N eurol., 352(1): 134-146.

Kimura, K., Oyama, F., Ueda, H., Mizuno,S. and Shimura, K. (1985). Molecular cloning of the fibroin light chain complementary DNA and its use in the study of the expression of the light chain gene in the posterior silk gland of Bombyx mori. Experientia, 41: 1167-1171.

Krishnaswami, S. (1986). New technology of silkworm rearing. Central Sericultural Research and Training Institute, Mysore, India.

Lowry, O.H., Rosenbrough, N.J., Farra, L. and Randall, R.J. (1951). Protein measurement with Folin phenol reagent. J Biol. Chem., 1933: 265-275.

Michaille, J.J., Garel, A. and Prudhomme, J.C. (1989). The expression of five middle silk gland specific genes is territorially regulated during the larval development of B ombyx mori. Insect Biochem., 19: 19-27.

Moore, S. and Stein, W.A. (1954). A modified ninhydrin reagent for the photometric determination of amino acids and related compounds. J. Biol. Chem., 211: 907-913.

Obara, T. and Suzuki, Y. (1988). Temporal and spatial control of silk gene transcription analyzed by nuclear run-on assay. Devl. Biol., 127: 384-391.

Peschel, N., Chen, K.F., Szabo, G. and Stanewsky, R. (2009). Light-dependent interactions between the Drosophila circadian clock factors cryptochrome, jetlag and timeless Curr. Biol., 19 (3): 241- 247.

Sailaja, B. and Sivaprasad, S. (2011). Photoperiod-induced clock-shifting in the circadian protein and amino acid rhythms in the larval fat body of silkworm, B ombyx mori. J . Appl. \& Nat. Sci., 3 (1): 38-50.

Sailaja, B. and Sivaprasad, S. (2010 a). Photoperiodic modulation of circadian rhythms in the silk gland protein profiles of Bombyx mori and its influence on the silk productivity and quality. J. Appl. \& Nat. Sci., 2 (1): 48-56.

Sailaja, B. and Sivaprasad, S. (2010 b). Photoperiodic modulation of circadian protein rhythm in the silk gland of B ombyx mori during fourth instar development. The Bioscan 5 (2): $177-183$.

Sehadova, H., Markova, E.P., Sehnal, F. and Takeda, M.(2004). Distribution of circadian clock related proteins in the cephalic nervous system of the silkworm, Bombyx mori. J . Biol.Rhythms, 19:466-482.

Shafer, T.O., Levine, J.D., Truman, J.W. and Hall, J.C. (2004). Flies by night: Effects of changing day length on D rosophila's circadian clock. Curr. Biol.,14 (5): 424-432.

Sivaprasad, S. (2010). Origin and peripheral distribution of the thoracic and abdominal median nerves in the fifth instar larva of the silkworm, Bombyx mori (Lepidoptera: Bombycidae). J. Appl. \& Nat. Sci., 2 (2): 251-257

Sivaprasad, S. and Muralimohan, P. (2009 a). Neuromuscular systems in the fifth instar larva of silkworm Bombyx mori(Lepidoptera: Bombycidae): I. Cephalothoracic musculature and its innervation. J. Appl. \& N at. Sci., 1(2): 201-209.

Sivaprasad, S. and Muralimohan, P. (2009 b). Neuromuscular systems in the fifth instar larva of silkworm Bombyx mori (Lepidoptera: Bombycidae): II. Abdominal musculature and its innervation. J. Appl. \& Nat. Sci., 1 (2): 210-226.

Stoleru, D., Peng, Y., Agosto, J. and Rosbash, M. (2004). Coupled oscillators control morning and evening locomotor behaviour of D rosophila. Nature, 431: 862-868.

Syrova, Z., Dolezel, D., Saumann, I. and Hodkova, M. (2003). Photoperiodic regulation of diapause in linden bugs: Are period and Clock genes involved? Cell. Mol. Life Sci., 60: 2510-2515.

Triplehorn, C.A. and Johnson, N.F. (2005). Borror and DeLong's Introduction to the Study of Insects ( $7^{\text {th }}$ Edition), Brooks / Thomson Cole, USA.

Xu, K., Zheng, X. and Seghal, A. (2008). Regulation of feeding and metabolism by neuronal and peripheral clocks in Drosophila. Cell M etabolism, $8: 289-300$.

Yamaoka, K., Hoshino, M. and Hirai, T.(1971). Role of sensory hairs on the anal papillae in oviposition behaviour of B ombyx mori. J . Insect Physiol., 47: 2327-2336.

Zhang, P. B., Aso, Y.K., Jikuya, H., Kusakabe, T., Lee, J.M., Kawaguchi, Y., Yamamoto, K., Banno, Y. and Fujii, H. (2007). Proteomic profiling of the silkworm skeletal muscle proteins during larval-pupal metamorphosis. J . Proteome Res., 6 (6): 2295-303. 